Provided for non-commercial research and education use. Not for reproduction, distribution or commercial use.

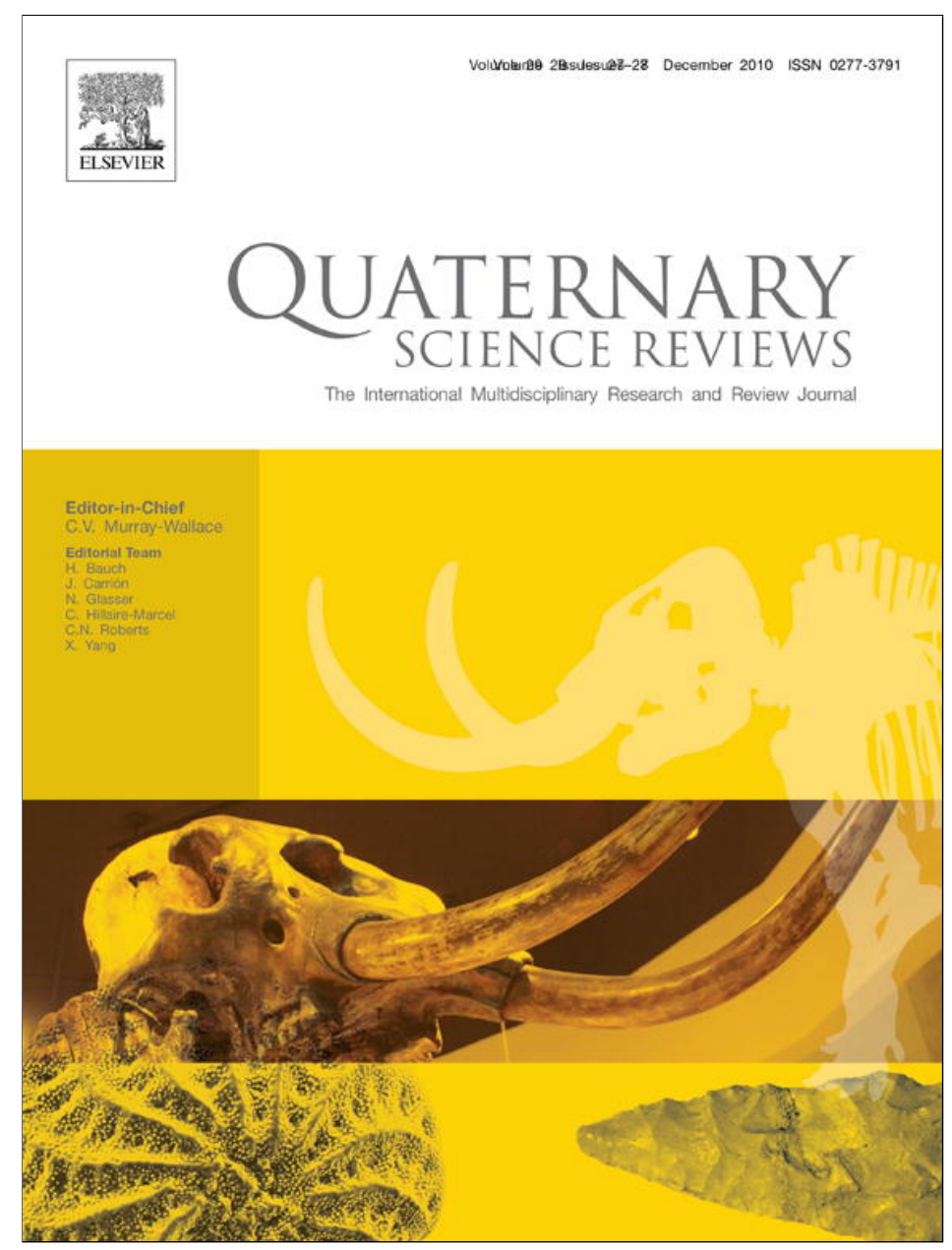

This article appeared in a journal published by Elsevier. The attached copy is furnished to the author for internal non-commercial research and education use, including for instruction at the authors institution and sharing with colleagues.

Other uses, including reproduction and distribution, or selling or licensing copies, or posting to personal, institutional or third party websites are prohibited.

In most cases authors are permitted to post their version of the article (e.g. in Word or Tex form) to their personal website or institutional repository. Authors requiring further information regarding Elsevier's archiving and manuscript policies are encouraged to visit:

http://www.elsevier.com/copyright 


\title{
Lateglacial and Holocene isotopic and environmental history of northern coastal Alaska - Results from a buried ice-wedge system at Barrow
}

\author{
Hanno Meyer ${ }^{\mathrm{a}, *}$, Lutz Schirrmeister ${ }^{\mathrm{a}}$, Andrei Andreev ${ }^{\mathrm{a}, \mathrm{f}}$, Dirk Wagner ${ }^{\mathrm{a}}$, Hans-W. Hubberten ${ }^{\mathrm{a}}$, \\ Kenji Yoshikawa ${ }^{b}$, Anatoly Bobrov $^{c}$, Sebastian Wetterich ${ }^{\text {a }}$, Thomas Opel ${ }^{a}$, Evgeniya Kandiano ${ }^{d}$, \\ Jerry Brown ${ }^{\mathrm{e}}$ \\ ${ }^{a}$ Alfred Wegener Institute for Polar and Marine Research, Research Unit Potsdam, Telegrafenberg A43, 14473 Potsdam, Germany \\ ${ }^{\mathrm{b}}$ Water and Environmental Research Center, Institute of Northern Engineering, University of Alaska, Fairbanks, AK 99775, USA \\ ${ }^{\mathrm{c}}$ Faculty of Soil Science, Moscow State University, Vorobievy Gory, 199899 Moscow, Russia \\ ${ }^{\mathrm{d}}$ Leibniz Institute of Marine Sciences, IFM-GEOMAR, 24148 Kiel, Germany \\ ${ }^{\text {e }}$ P.O. Box 7, Woods Hole, MA 02543, USA \\ ${ }^{\mathrm{f}}$ University of Cologne, Institute of Geology and Mineralogy, Zülpicher Str. 49a D-50674 Köln, Germany
}

\section{A R T I C L E I N F O}

\section{Article history:}

Received 28 September 2009

Received in revised form

3 August 2010

Accepted 4 August 2010

\begin{abstract}
A B S T R A C T
Barrow, the northernmost point in Alaska, is one of the most intensively studied areas in the Arctic. However, paleoenvironmental evidence is limited for northern Alaska for the Lateglacial-Holocene transition. For a regional paleoenvironmental reconstruction, we investigated a permafrost ice-wedge tunnel near Barrow, Alaska. The studied site was first excavated in the early 1960s and intercepts a buried ice-wedge system at 3-6 $\mathrm{m}$ depth below the surface. A multi-methodological approach was applied to this buried ice-wedge system and the enclosing sediments, which in their combination, give new insight into the Late Quaternary environmental and climate history. Results of geochronological, sedimentological, cryolithological, paleoecological, isotope geochemical and microbiological studies reflect different stages of mid to late Wisconsin (MW to LW), Allerød (AD), Younger Dryas (YD), Preboreal (PB), and Late Holocene paleoenvironmental evolution. The LW age of the site is indicated by AMS dates in the surrounding sediments of $21.7 \mathrm{kyr}$ BP at the lateral contact of the ice-wedge system as well as $39.5 \mathrm{kyr}$ BP below the ice-wedge system. It is only recently that in this region, stable isotope techniques have been employed, i.e. to characterize different types of ground ice. The stable isotope record (oxygen: $\delta^{18} \mathrm{O}$; hydrogen: $\delta D$ ) of two intersecting ice wedges suggests different phases of the northern Alaskan climate history from $\mathrm{AD}$ to $\mathrm{PB}$, with radiocarbon dates from 12.4 to $9.9 \mathrm{kyr} \mathrm{BP}$ (ranging from 14.8 to $10.6 \mathrm{kyr}$ cal $\mathrm{BP})$. Stable isotope geochemistry of ice wedges reveals winter temperature variations of the Lateglacial -Holocene transition including a prominent YD cold period, clearly separated from the warmer AD and PB phases. YD is only weakly developed in summer temperature indicators (such as pollen) for the northern Alaska area, and by consequence, the YD cold stadial was here especially related to the winter season. This highlights that the combination of winter and summer indicators comprehensively describes the seasonality of climate-relevant processes in discrete time intervals. The stable isotope record for the Barrow buried ice-wedge system documents for the first time winter climate change at the Lateglacial-Holocene transition continuously and at relatively high (likely centennial) resolution.
\end{abstract}

(c) 2010 Elsevier Ltd. All rights reserved.

\section{Introduction}

The Lateglacial to Early Holocene transition of the global climate lasting about $2.5 \mathrm{kyr}$ covers the Allerød (AD) warming, the Younger Dryas (YD) cooling, and the Preboreal (PB) warming phases. Paleoenvironmental reconstructions for this critical transitional period

\footnotetext{
* Corresponding author.

E-mail address: hanno.meyer@awi.de (H. Meyer).
}

are limited for northern Alaska, but may add important information to regional and global, spatial and temporal correlations. Mann et al. (2002) provide stratigraphic evidence from an Alaskan Arctic Foothill site for the tundra landscape responses to climatic change for the period 13-8 kyr BP. Eisner et al. (2005) document an early phase of high productive plant growth at ca $8 \mathrm{kyr}$ BP from an erosional remnant on the northern Arctic Coastal Plain. MacDonald et al. (2006) correlate early peatland development on a circumarctic basis beginning around $16.5 \mathrm{kyr}$ BP and expanding rapidly between 12 and 8 kyr BP. Numerous regional pollen records reflect 
a rapid transformation of the vegetation communities from herbdominated tundra to birch-dominated shrub tundra ca 14-12 kyr BP (e.g. Ager, 1982; Brubaker et al., 1983; Anderson, 1985, 1988; Anderson et al., 1988; Eisner and Colinvaux, 1992; Anderson and Brubaker, 1994). The largest regional environmental impact was the reopening of the Bering Strait between 12 and $11 \mathrm{kyr}$ BP (Hopkins, 1982; Keigwin et al., 2006).

Strong temperature variations in the Arctic during the Late Pleistocene to Early Holocene transition are well documented by $\delta^{18} \mathrm{O}$ changes in Greenland ice cores (e.g. Alley, 2000). Similar variations are obvious in the stable isotope composition of ice wedges along the Laptev Sea coast, northeast Siberia (Meyer et al., 2002a, b) that are likely related to winter temperature changes.

This investigation focuses on the Lateglacial and Early Holocene environmental history recorded in a buried ice-wedge system and its enclosing permafrost deposits. Within the framework of permafrost investigations conducted at Barrow, Alaska, in the early 1960s a team of scientists from the Cold Regions Research and Engineering Laboratory (CRREL) excavated an approximate 9 meters long and $1.5 \mathrm{~m}$ high buried ice-wedge system (Brown, 1963, $1965,1967)$. The site was re-sampled in 2004 and 2006 by a team from Alfred Wegener Institute for Polar and Marine Research (AWI) in Potsdam. Neither radiocarbon AMS dating nor stable isotope techniques were readily available in the 1960s. Therefore, the first step in our current investigations was to reconfirm and refine the age estimate of the site based on modern AMS dating technologies.

Permafrost tunnels offer unique three-dimensional underground insight into structures and compositions of the frozen ground including the enclosed ground ice. Such observational sites allow very detailed stratigraphic studies of both ground ice and permafrost deposits and the opportunity to obtain undisturbed and clean samples for numerous analytical approaches. With stable ground temperatures well below $0^{\circ} \mathrm{C}$ (mean annual ground temperature of $-10^{\circ} \mathrm{C}$ ), this site serves as "permafrost laboratory" and can be revisited if the data require re-sampling for further understanding of the system and its surroundings.

A series of papers were published about the site including radiocarbon dating of buried and ice-included organics and chemical analyses of sediments and soil (Brown, 1963, 1965, 1967, 1969a, 1969b; Brown and Sellmann, 1966). Colinvaux (1964) presented paleo-ecological interpretations based on pollen recovered from the buried ice wedge $(14,000 \pm 500 \mathrm{yr} \mathrm{BP})$ and overlying frozen organic materials.
In 2004, the access to the permafrost tunnel, previously sealed by seepage of surface water into the access shaft, was reopened. During spring of 2004 and 2006, detailed description and sampling of ground ice, sediment, ice texture and fossils preserved in the frozen ground were carried out. The main objectives of the new investigation were: (1) to conduct a stable isotope characterization of the ground ice for a reconstruction of the winter temperatures at the time of their formation that was previously not feasible; (winter is in this manuscript defined as the period, where precipitation falls as snow); (2) to review the site's geochronology in light of new dating techniques (i.e. AMS radiocarbon dating) and field observations; and (3) to undertake new sedimentological, geocryological, paleoecological, as well as microbiological studies for a detailed characterization of permafrost and landscape development from this part of the Alaskan Arctic Coastal Plain. The multi-methodological approach and especially the combination of winter (ground ice) and summer (pollen) indicators are assumed to give new insight into the local and regional environmental history. We present pore water and modern precipitation stable isotope data at Barrow as well as a comprehensive lithostratigraphical and geochronological classification of the permafrost tunnel as a basis for a detailed paleoenvironmental interpretation of ground ice.

\section{Regional setting}

The Arctic Slope of Alaska consists of three major physiographic provinces: the Brooks Range, the Arctic Foothill, and the Arctic Coastal Plain and covers about $200,000 \mathrm{~km}^{2}$. The Inaru River is the only river that lies entirely within the Coastal Plain and discharges into the Dease Inlet to the east of Barrow. The Barrow Peninsula $\left(71^{\circ} 18^{\prime} \mathrm{N}\right.$, $156^{\circ} 40^{\prime} \mathrm{W}$ ) is situated at the northern extremity of the Arctic Coastal Plain bordered on the west by the Chukchi Sea and to the east by the Beaufort Sea and its lagoon complexes (Fig. 1). In the local area, elevations range from 3 to $5 \mathrm{~m}$ along Elson Lagoon on the east and rise to the southwest to over $10 \mathrm{~m}$. The $100 \mathrm{~m}$ bathymetric contour on the Chukchi Sea side is $17 \mathrm{~km}$ offshore and $26 \mathrm{~km}$ on the Beaufort side (Brown et al., 2003). Continuous permafrost up to $300 \mathrm{~m}$ thick underlies all land surfaces at Barrow (Brewer, 1958; Jorgenson et al., 2008). The mean annual ground temperatures at depths of 20 to $30 \mathrm{~m}$ below surface reach -9 to $-9.5^{\circ} \mathrm{C}$ (Nelson et al., 2008).

The coastal climate is characterized by long, dry cold winters and short, moist cool summers, and is moderated by the proximity of the ocean. The mean annual air temperature is $-12.0^{\circ} \mathrm{C}$ and

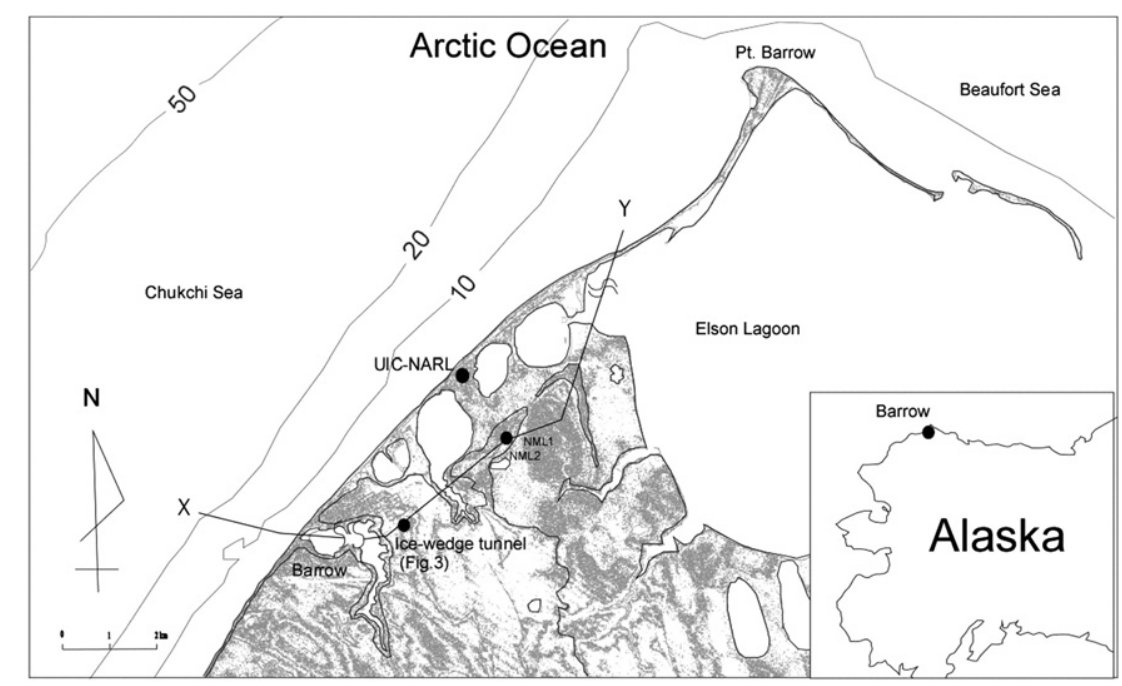

Fig. 1. Setting of the buried ice-wedge system near Barrow, Alaska, where $\mathrm{X}-\mathrm{Y}$ indicate the position of the cross section displayed in Fig. 2. 
mean annual precipitation is $106 \mathrm{~mm}$ (Barrow airport, 1971-2000), more than $50 \%$ falling in the short summer period (NOAA, 2002). The windblown snow cover reaches a thickness of $20-40 \mathrm{~cm}$. The Barrow Peninsula is dominated by wet, acidic soils. The average thickness of the active layer is less than $40 \mathrm{~cm}$.

The Arctic Coastal Plain was unglaciated during the Late Pleistocene (Kaufman and Manley, 2004). Its sediments are mainly composed of near-shore marine, fluvial, alluvial and eolian deposits of Middle to Late Quaternary age. The deposits, termed the Gubik Formation, are seldom thicker than $30 \mathrm{~m}$ and overlie rocks of Cretaceous and Tertiary age (Black, 1964; Sellmann and Brown 1973). The Gubik Formation is subdivided into the Barrow and the Skull Cliff Units. Sellmann and Brown (1973) summarized the local stratigraphy of the Barrow region using additional results from their drilling and other available subsurface information.

Regional sediments of the Barrow area are largely the product of a series of marine transgressions. Based on a recent unpublished radiocarbon date ( $>46,890 \mathrm{yr}$ BP; pers. comm. Julie Brigham-Grette) from the inland beach ridge with an elevation of $10 \mathrm{~m}$ (Fig. 2), the age of the last major transgression was reassigned to the Simpsonian transgression (70 kyr ago) by Brigham (1985). The Late Quaternary landscape dynamics of the outer Arctic Coastal Plain and in particular the Barrow area are characterized by a changing sea level. Widely distributed fossil beach lines point to a series of transgressions during Marine Isotope Stage (MIS) 5e (Pelukian Transgression; Brigham-Grette and Hopkins, 1995). During the Last Glacial Maximum (LGM) the sea level dropped down to $-90 \mathrm{~m}$ in the Bering Sea as compared to the modern sea level, down to $-97 \mathrm{~m}$ in the western Beaufort Sea, and down to about $-115 \mathrm{~m}$ at the Alaskan-Canadian boundary (Hopkins, 1982). Since $15.5 \mathrm{kyr}$ BP, the global sea-level rise lead to the flooding of the Bering Land Bridge (Hopkins, 1982). The opening of the Bering Strait was dated between about 12 and $11 \mathrm{kyr}{ }^{14} \mathrm{C} \mathrm{BP}$ (Elias et al., 1996). The inflow of Pacific water through the Bering Strait brought first Pacific bivalves to the Arctic Ocean at about $13 \mathrm{kyr}$ cal BP (Bradley and England, 2008).

The present periglacial landscape of the Barrow peninsula is characterized by large, elliptical, oriented lakes covering up to $22 \%$ of the surface (Hinkel et al., 2003, 2005). The remaining land surface is composed of tundra covered drained-lake basins (up to $50 \%$, and polygonal ground. The latter is the result of intensive icewedge growth in the upper $2-4 \mathrm{~m}$. The ice wedges grow over many thousands of years as snow melt water penetrate thermal contraction cracks that develop during the winter as the ground contracts (Lachenbruch, 1962). The soils, lake-basin sediments, and the upper permafrost zone contain relatively large amounts of organic carbon (Hinkel et al., 2003).

Both the shallow lakes and the deeper lakes with underlying thaw bulbs (taliks) are effective agents of thermokarst as they remove the excessive segregated ice and ice wedges by melting, thus resulting in settlement or lowering of the land surface or lake bottom. The remaining ice-rich elevations have been referred as remnants of a primary land surface not recently affected by thaw lake migration (Hussey and Michelson, 1966). The investigated permafrost ice-wedge tunnel is located at an elevation of about $8.3 \mathrm{~m}$ a.s.l., between the Middle Salt Lagoon to the east and the Esatkuat Lagoon and the town Barrow to the west (Figs. 1 and 2; Brown, 1963, 1969a, b). This elevation is bordered to the east by a series of drained lake basins (see Brown et al., 1980, Fig. 1).

\section{Material and methods}

\subsection{Fieldwork and site description}

The Barrow permafrost tunnel intercepts a buried ice-wedge system horizontally about $10 \mathrm{~m}$ in $\mathrm{E}-\mathrm{W}$ direction and $3 \mathrm{~m}$ in $\mathrm{N}-\mathrm{S}$ direction (Figs. 3 and 4). The ice-wedge system is covered by about $3.5 \mathrm{~m}$ of tundra soil and frozen ice-rich deposits that contain small, buried ice wedges and relatively large, active near surface ice wedges (Brown, 1967). The new entrance shaft reaches the ice wedge level at $3.6 \mathrm{~m}$ depth below surface (m b.s.). An insulating gravel fill was placed on the original ground surface to protect the permafrost from thawing. Perennially frozen sediments are exposed in the access shaft from 0.15 to $3.5 \mathrm{~m}$ b.s., at the eastern end of the tunnel from 3.9 to $4.5 \mathrm{~m}$ b.s. and within the drill hole B3 in the tunnel bottom from 6.8 to $7.7 \mathrm{~m}$ b.s. (Fig. 3). Sampling of sediments was carried out by means of an axe and a hammer in the access shaft and at the end of the tunnel following a detailed cryolithological description.

The buried ice-wedge system was sampled for stable isotopes in horizontal direction at a depth of $4.5 \mathrm{~m}$ below the surface and about $50 \mathrm{~cm}$ above the floor of the permafrost tunnel (Fig. 3). In total, 59 samples were taken from ice wedges in 2004 (sampling transect $\mathrm{A}-\mathrm{A}^{\prime}$ ) and 72 samples in 2006 (sampling transects $\mathrm{B}-\mathrm{B}^{\prime}, N=12$; $\left.\mathrm{C}-\mathrm{C}^{\prime}, N=33 ; \mathrm{D}-\mathrm{D}^{\prime}, N=16 ; \mathrm{E}-\mathrm{E}^{\prime}, N=11\right)$. Transects $\mathrm{A}-\mathrm{A}^{\prime}, \mathrm{B}-\mathrm{B}^{\prime}$ and D-D ${ }^{\prime}$ were sampled with the use of an electric chain saw $(1.5 \mathrm{~cm}$ slices in $10 \mathrm{~cm}$ intervals). The widths of single ice veinlets vary between 1 and $6 \mathrm{~mm}$. Thus, one sample (width: $15 \mathrm{~mm}$ ) represents an integral signal of several (up to 15) ice veins. Sampling transects $\mathrm{C}-\mathrm{C}^{\prime}$ and $\mathrm{E}-\mathrm{E}^{\prime}$ were drilled in the horizontal direction with a small auger $(4 \mathrm{~cm}$ in diameter) and samples were taken in $10 \mathrm{~cm}$ resolution. All ice samples were transported frozen to the cold laboratory at AWI (Bremerhaven, Germany), where they were cut for further analyses.

At drill holes $\mathrm{C}-\mathrm{C}^{\prime}$ and $\mathrm{E}-\mathrm{E}^{\prime}$, the horizontal contact between ice wedge and sediment was reached at a distance of $3.0 \mathrm{~m}$ and $1.1 \mathrm{~m}$ from the tunnel wall, respectively. This leads to apparent widths of two intersecting ice wedges of between $5.5 \mathrm{~m}$ and $6.5 \mathrm{~m}$ (Fig. 4).

At the lower end of the new access shaft, the upper contact of the ice-wedge system was sampled separately in order to study exchange processes between ice and sediment (Fig. 3). For this purpose, an ice block including the uppermost $7 \mathrm{~cm}$ of the ice wedge was taken and subsequently subsampled in horizontal $1 \mathrm{~cm}$

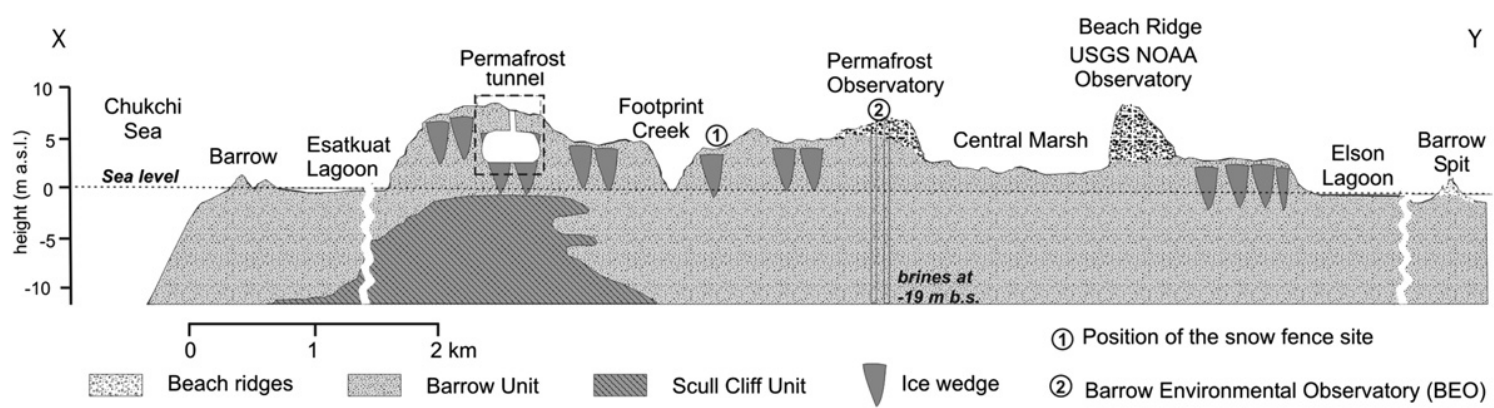

Fig. 2. Generalized stratigraphic cross section $(X-Y)$ of the Barrow area (based on Sellmann and Brown, 1973). 


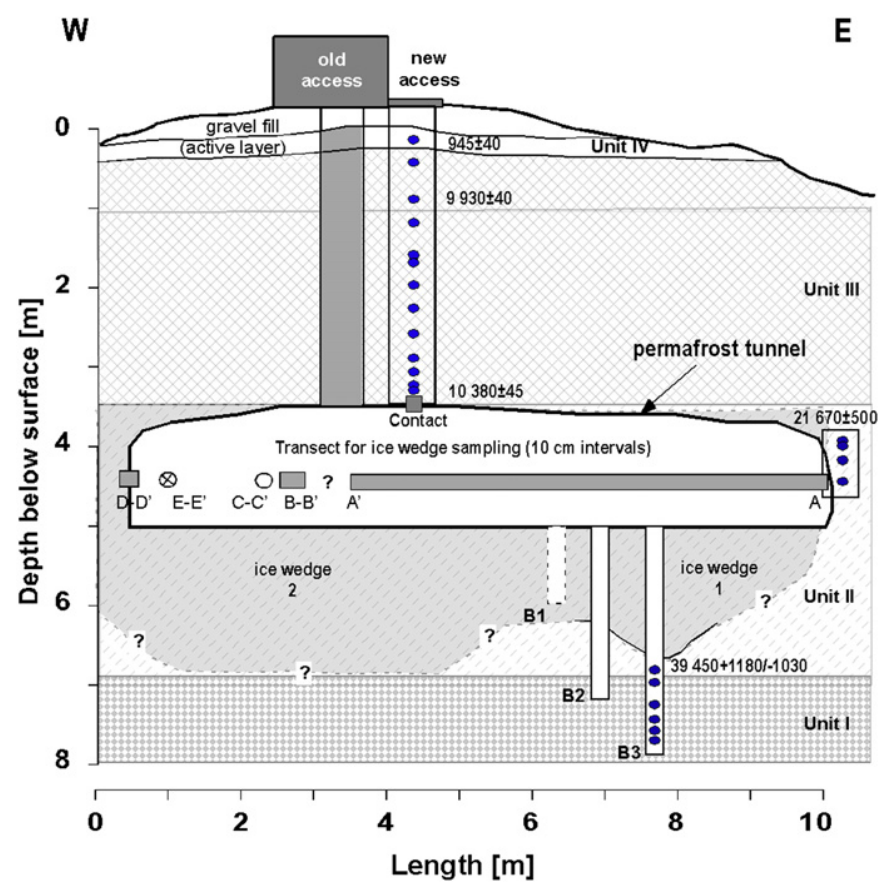

Fig. 3. Schematic drawing of the Barrow ice-wedge system (side view) with sediment and ice sample positions. Dots mark sediment samples in the shaft, in the borehole B3 and of the lateral contact of the ice wedge including associated radiocarbon dates ( $y r \mathrm{BP}$ ). Grey sections indicate the sampling transects of the ice wedge and the sampling of the interface top ice wedge - sediment.

wide slices in the cold laboratory. Each of these slices contained the same series of subvertical ice veins, but with increasing distance to the upper contact of the ice wedge. These samples are excluded from the paleoenvironmental interpretation of the ice wedges.

\subsection{Analytical methods}

\subsubsection{Sedimentology and geocryology}

Frozen sediments were freeze-dried and subsampled for sedimentological, geochemical and paleoecological analysis. Before and after the drying process the sediment samples were weighed in

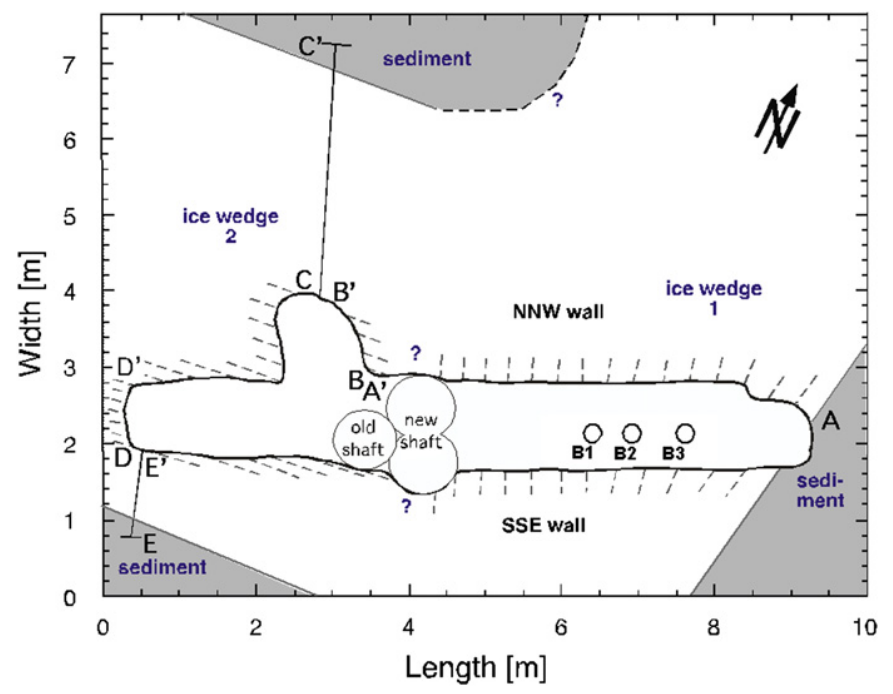

Fig. 4. Schematic drawing of the Barrow ice-wedge system (top view) showing position of sample transects. Additionally, the orientation of ice wedge foliations is displayed (dashed grey lines). order to measure the gravimetric ice content. Specific electrical conductivities were measured with a WTW conductometer (normalized to $25^{\circ} \mathrm{C}$ ). Grain size analyses were performed with a laser particle analyzer LS 200 (Fa. Beckman-Coulter). The contents of total organic carbon (TOC), total carbon (TC) and total nitrogen (TN) were measured with a CNS Elementar Analyzer VARIO-EL-III. Total inorganic carbon (TIC) content was calculated after decalcification of the samples by subtraction of TOC from TC. The samples were decalcified for $3 \mathrm{~h}$ at $95^{\circ} \mathrm{C}$ by adding a surplus of $1.3 \mathrm{~N} \mathrm{HCl}$ to the sediment sample prior to TIC analysis. The $\delta^{13} \mathrm{C}$ values of TOC were measured with a Finnigan DELTA S mass spectrometer and are expressed in delta per mil notation $(\delta, \%)$ relative to the Vienna Pee Dee Belemnite (V-PDB) standard. The accuracy of these measurements is better than $0.2 \%$. In general, variations in $\delta^{13} \mathrm{C}$ may be indicative of changes in the local plant association and the decomposition of organic matter (Hoefs, 1997). Mass-specific magnetic susceptibility controlled by the content of magnetic minerals in the sediment is frequently used for paleoenvironmental studies of terrestrial as well as marine Late Quaternary series. The analyses were carried out using BARTINGTON MS2 and MS2B instruments equipped with the sensor type MS2B. The results are expressed in $10^{-8} \mathrm{~m}^{3} \mathrm{~kg}^{-1}$.

\subsubsection{Radiocarbon dating}

The ages of the sediments as well as of the ice wedges in the buried section were determined by Accelerator Mass Spectrometry (AMS) ${ }^{14} \mathrm{C}$ dating of plant remains (mainly small roots, leaves or twigs) sampled under a light microscope. The measurements were carried out in the Leibniz Laboratory in Kiel, Germany. Details of the AMS facility in Kiel are given in Nadeau et al. (1997) and Nadeau et al. (1998). In order to eliminate contamination by younger organic acids, only the leached residues were used for dating. AMS ${ }^{14} \mathrm{C}$ ages were calibrated using the CALIB rev. 5.02 Software, Calibration dataset: intcal04.14c (Reimer et al., 2004).

\subsubsection{Stable water isotopes}

Hydrogen and oxygen isotope ratios were measured with a Finnigan MAT Delta-S mass spectrometer at the AWI in Potsdam using equilibration techniques. They are given as per mil difference to V-SMOW ( $\%$, Vienna Standard Mean Ocean Water), with internal $1 \sigma$ errors of better than $0.8 \%$ and $0.1 \%$ for $\delta D$ and $\delta^{18} \mathrm{O}$, respectively (Meyer et al., 2000). Highly saline (brine) samples are difficult to measure with the equilibration method used in this study (Kohfahl et al., 2008) and might be erroneous by up to $10 \%$ in $\delta D$ and $1 \%$ in $\delta^{18} \mathrm{O}$. The results are presented in $\delta^{18} \mathrm{O}-\delta D$ diagrams with respect to the Global Meteoric Water Line (GMWL; $\delta D=8 \delta^{18} \mathrm{O}+10$ ), a linear correlation of global fresh surface waters (Craig, 1961), and to the Local Meteoric Water Line (LMWL) of Barrow $(\delta D=7.12$ $\delta^{18} O-9.13 ; R^{2}=0.94 ;$ IAEA, 2006). In general, the most negative $\delta^{18} \mathrm{O}$ and $\delta D$ values reflect the coldest temperatures. Slope and intercept in the $\delta^{18} \mathrm{O}-\delta D$ diagram are valuable indicators for the identification of (1) precipitation deriving from the evaporation of ocean water in different regions and (2) participation of secondary evaporation processes (Dansgaard, 1964). The deuterium excess $\left(d=\delta D-8 \delta^{18} \mathrm{O}\right)$ introduced by Dansgaard (1964) is an indicator for kinetic (non-equilibrium) fractionation processes and generally related to conditions (humidity, sea surface temperature, wind speed) in the initial moisture source region.

\subsubsection{Paleoecology}

Fossil bioindicators (i.e. pollen, spores, ostracods, foraminifers, testate amoebae) preserved in frozen sediments have been analyzed in order to obtain paleoenvironmental information.

Pollen samples were prepared using standard techniques (Faegri and Iversen, 1989). For each sample, 200-300 terrestrial 
pollen grains and spores were counted at $400 \times$ magnification under the light microscope. The relative frequency of pollen was calculated based upon the tree and herb pollen sum. The percentage of spores, redeposited taxa, and algae are based on the sum of pollen and the respective group (e.g. pollen + spores; pollen + algae, etc.) (Berglund and Ralska-Jasiewiczowa, 1986). For graphical presentation of the pollen data the TILIA software was used (Grimm, 1991).

For analyses of ostracods about $200 \mathrm{~g}$ per sediment sample were wet-sieved through a $0.25 \mathrm{~mm}$ mesh screen, and then air-dried. Ostracod valves were identified under a stereo-microscope according to Meisch (2000).

For foraminifer analysis, three samples from frozen sediments below and next to the buried ice-wedge system were used. The samples were freeze-dried, washed over a $63 \mu \mathrm{m}$ sieve, dried at $50{ }^{\circ} \mathrm{C}$ and finally examined under light microscope.

Testate amoebae (rhizopods) were analyzed for characterization of paleosol conditions. The significance of such analysis for paleoecological studies is based on the fact that testate amoebae are permanently attached to the substrate. Commonly their shells (testa) are destroyed if sediments are reworked and redeposited. Therefore, these testa indicate the in-situ paleoenvironmental conditions during sedimentation, unlike many other biological remains. Samples for testate amoebae analysis were sieved through a $0.5 \mathrm{~mm}$ mesh and testate amoebae shells were concentrated in a centrifuge. A drop of suspension was placed on the slide, and glycerol added. Normally, five subsamples per sample were examined at 200-400× magnification with a light microscope.

\subsubsection{Microbiology}

Methane $\left(\mathrm{CH}_{4}\right)$ concentrations were analyzed by extracting $\mathrm{CH}_{4}$ from six ice-wedge samples in order to examine the temporal variability of $\mathrm{CH}_{4}$ production by microorganisms in a cold permafrost environment. Approximately $10 \mathrm{~g}$ of frozen ground ice were placed in glass jars filled with saturated $\mathrm{NaCl}$ solution. The samples were then sealed gas tight with black rubber stoppers. The samples were thawed, shaken and the $\mathrm{CH}_{4}$ headspace concentration was analyzed with an Agilent 6890 gas chromatograph equipped with a carbon plot capillary column $(\varnothing 0.52 \mathrm{~mm}, 30 \mathrm{~m})$ and a flame ionization detector (FID).

The potential metabolic activity of methanogenic archaea (methane producing microorganisms) was analyzed by anoxic incubation of 12 frozen sediment samples with hydrogen as a substrate. The incubation temperature was $10^{\circ} \mathrm{C}$. Gas samples were taken every $24 \mathrm{~h}$ out of the jars headspace with a gas-tight syringe. Methane production was calculated from the linear increase in $\mathrm{CH}_{4}$ concentration analyzed by gas chromatography. The number of chemo-organotrophic bacteria (COB) was determined by plate counts on BR agar (Bunt and Rovina, 1955). Plates were incubated for one week at $18^{\circ} \mathrm{C}$. More details about the methods applied for microbial activity studies can be found in Wagner et al. (2007).

\section{Results}

\subsection{Sedimentological, cryolithological and geochronological studies}

The new access shaft, the western end of the tunnel as well as new boreholes in the tunnel bottom exposed a sequence of frozen deposits between 0.15 and $7.7 \mathrm{~m}$ below the former ground surface (Fig. 3). Four units (I, II, III, IV) are clearly differentiated in sedimentological, cryolithological, and geochronological data (Figs. 5 and 6).

The lowermost unit I was recovered in the boreholes B2 and B3 between 7.0 and $7.7 \mathrm{~m}$ depth, about $1.5 \mathrm{~m}$ below the base of the icewedge system (Fig. 3). This material consists of a mixture of

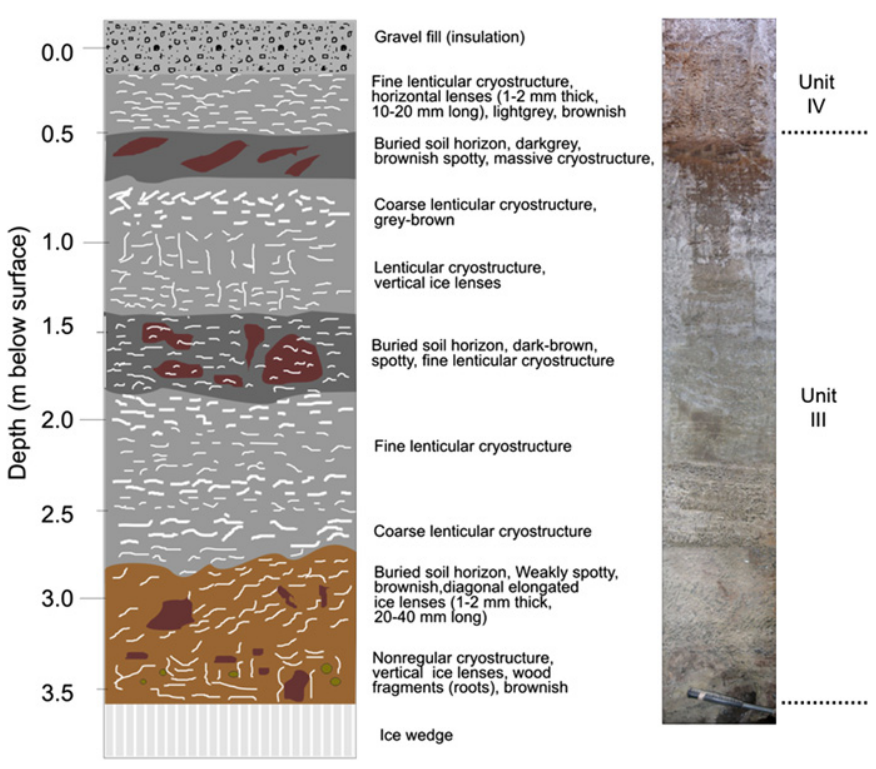

Fig. 5. Cryolithological profile of the shaft wall.

unfrozen (liquid-like) dark-grey silty and gravelly fine to mediumgrained sand. The sediment was unfrozen (but below $0{ }^{\circ} \mathrm{C}$ ), because of the high salinity of pore water (electrical conductivity of $119,800 \mu \mathrm{S} \mathrm{cm}^{-1}$ ). Brown (1969b) had previously drilled, sampled and reported this high salt zone. Unit I was underlain by coarse material, which was observed but could not be sampled with the drilling equipment available. The sediments of unit I contain $0.5-1.8 \mathrm{wt} \%$ of organic carbon and show the highest magnetic susceptibility of about $30-84 \times 10^{-8} \mathrm{~m}^{3} \mathrm{~kg}^{-1}$. The uppermost sediment sample within the borehole B3 in $6.8 \mathrm{~m}$ depth dated to $39.5 \mathrm{kyr}$ BP (Table 1 ) has a low magnetic susceptibility of only $13 \times 10^{-8} \mathrm{~m}^{3} \mathrm{~kg}^{-1}$, similar to the frozen samples collected at the ice wedge-sediment contact at the eastern end of the tunnel, which were attributed to sediment unit II (Fig. 6).

The yellowish-grey deposits of unit II are characterized by massive cryostructure and gravimetric ice content (relative to dry sample) of $26-50 \mathrm{wt} \%$. The poorly sorted fine-grained sandy silt contains only small quantities of organic carbon (0.4-0.5 wt\%), which was dated to about $21.7 \mathrm{kyr}$ BP at the 4.0-4.2 m depth (Table 1 ). The stable carbon isotope compositions of bulk organic matter are significantly heavier $(-25.8$ to $-25.1 \%$ ) than in the deposits above ( -26.9 to $-28.2 \%$ ) (Fig. 6 ).

Unit III, exposed in the shaft between 0.4 and $3.6 \mathrm{~m}$ depth, is composed of an alternation of poorly sorted, medium- to finegrained gravely sand, sandy silt and peaty silt. The cryostructure is dominantly lenticular, but varies in size of the ice lenses (coarse to fine lenticular) and inclination (horizontal, diagonal, vertical) (Fig. 5). The gravimetric ice content varies between 24 and $200 \mathrm{wt} \%$. These cryolithological features are evident for ice-saturated to supersaturated conditions and repeated thaw-freeze processes. Unit III was accumulated between 10.4 and $9.9 \mathrm{kyr} \mathrm{BP}$ (corresponding to 12.6-11.2 cal kyr BP). Three buried cryosol horizons were observed in unit III at depths of $0.5-1 \mathrm{~m}, 1.5 \mathrm{~m}$, and $3-3.6 \mathrm{~m}$, respectively (Fig. 5). The buried cryosols are evident by brownish spotty soil texture and a fine-lenticular cryostructure. The upper and lower cryosols are furthermore characterized by relatively high contents of organic carbon as well as higher TOC/TN ratios between 10 and 20 indicating weaker decomposition of organic matter (Fig. 6). The upper buried cryosol dated to $9.9 \mathrm{kyr} \mathrm{BP}$ (Table 1 ) is characterized by higher values of magnetic susceptibility, highest ice contents (100-200 wt\%) and TOC values (30 wt\%). 


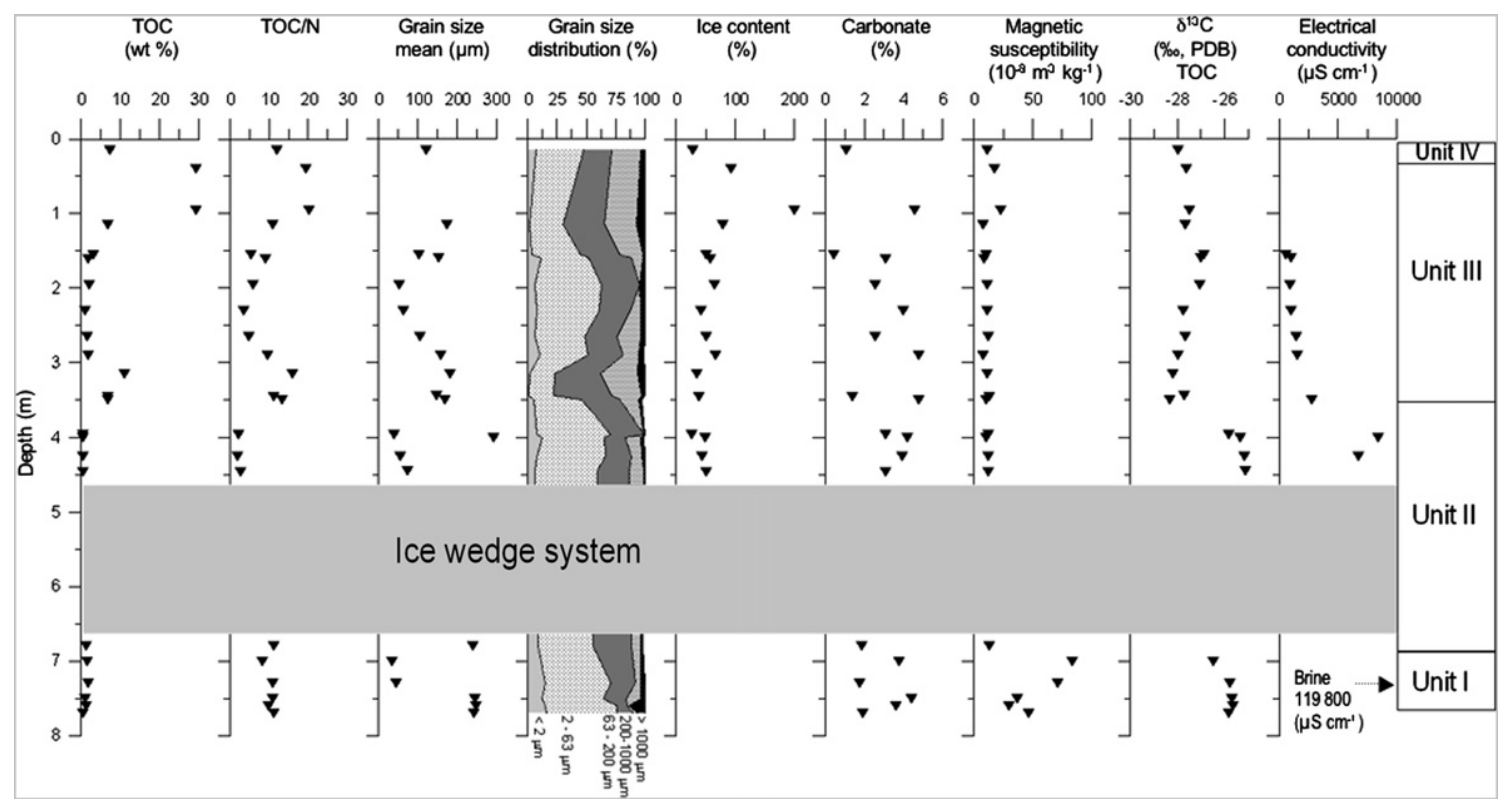

Fig. 6. Sedimentological analyses and stratigraphic subdivision of the permafrost sections surrounding the buried ice-wedge system.

The uppermost unit IV is composed of peaty silt and assigned to the Late Holocene because of a radiocarbon age of $945 \mathrm{yr}$ BP. Their cryolithological as well as sedimentological characteristics are similar to the underlying unit III. Unit IV represents the modern active layer. This soil and its buried organic horizon was radiocarbon dated and reported upon at a location immediately adjacent to the shaft and overlying a large modern, active ice wedge (Brown, 1967). These buried organic horizons are subject to cryoturbation processes common in all wet tundra soil underlain by permafrost.

Plant remains within the ice wedges were radiocarbon dated between 12.4 and $9.9 \mathrm{kyr}$ BP, respectively 14.8-10.6 cal kyr BP (Table 1). Thus, we estimate that the ice-wedge system was formed in about 3000 years initiated in the AD interstadial and terminated in the PB, when it was buried by additional sedimentation.

\subsection{Paleoecological indicators}

The lowermost pollen spectra from unit I are likely older than 40 kyr BP (pollen zone 1: PZ-1; Fig. 7). Poaceae and Artemisia with some Cyperaceae, Caryophyllaceae and Asteraceae are dominant. High amounts of green algae colonies (Pediastrum and Botryoccous) and mineralized Tertiary pollen (Pinaceae) and spores of reworked origin are also characteristic for the zone. The total pollen concentration is low (770-4200 grains per g) reflecting sparse vegetation during the Middle Wisconsin. Relatively high amounts of Picea, Pinus, Betula and other tree and shrub pollen are of reworked origin. We assumed poorly-preserved and mineralized pollen as obviously redeposited taxa. Open grass-Artemisia communities dominated vegetation at this time indicating cold and dry climate conditions. However, the high amounts of green algae colonies suggest that sedimentation took place in shallow water environment.

The pollen spectrum from $7 \mathrm{~m}$ depth is different from all other studied spectra in PZ-I, because it contains numerous Cyperaceae, tree and shrub pollen (Picea, Pinus, Betula, and Alnus) as well as reworked Pinaceae. It is very likely that pollen found in this spectrum are mostly reworked, therefore they have not been used for paleoenvironmental interpretation for this unit.

Table 1

Radiocarbon dating of organic remains in both frozen sediments and ice wedges of the Barrow permafrost tunnel.

\begin{tabular}{|c|c|c|c|c|c|c|c|}
\hline \multirow[b]{2}{*}{ Sediment } & \multirow{2}{*}{$\begin{array}{l}\text { Depth } \\
{[\mathrm{m}]} \\
0.15\end{array}$} & \multirow{2}{*}{$\begin{array}{l}\text { Sample ID } \\
\text { BAR-1/1 }\end{array}$} & \multicolumn{2}{|c|}{$\begin{array}{l}\text { Radiocarbon age } \\
\text { [yr BP] }\end{array}$} & \multirow{2}{*}{$\begin{array}{l}\text { Calibrated age } \\
2 \sigma \text { range [yr cal BP] } \\
932-768\end{array}$} & \multirow{2}{*}{$\begin{array}{l}\text { Mean calibrated } \\
\text { age [yr cal BP] } \\
850\end{array}$} & \multirow{2}{*}{$\begin{array}{l}\text { Lab ID } \\
\text { KIA } 25273\end{array}$} \\
\hline & & & 945 & \pm 40 & & & \\
\hline & 0.95 & BAR $1 / 3$ & 9930 & \pm 40 & $11,602-11237$ & 11,420 & KIA 24874 \\
\hline & 3.45 & BAR $1 / 9$ & 10,380 & $+45 /-40$ & $12,572-12060$ & 12,316 & KIA 24875 \\
\hline & $4-4.2$ & BAR $1 / 11+1 / 12$ & 21,670 & $+500 /-470$ & & & KIA 24876 \\
\hline & 6.8 & BAR 3/1 & 39,450 & $+1180 /-1030$ & & & KIA 31129 \\
\hline & $\begin{array}{l}\text { Isotope } \\
\text { cluster }\end{array}$ & Sample ID & $\begin{array}{l}\text { Radioca } \\
\text { [yr BP] }\end{array}$ & & $\begin{array}{l}\text { Calibrated age } \\
2 \sigma \text { range [yr cal BP] }\end{array}$ & $\begin{array}{l}\text { Mean calibrated } \\
\text { age [yr cal BP] }\end{array}$ & Lab ID \\
\hline \multirow{10}{*}{$\begin{array}{l}\text { Ice wedges } \\
\text { (sampled in a } \\
\text { depth of } 4.5 \mathrm{~m} \text { ) }\end{array}$} & $\overline{1}$ & BAR-IW- $-{ }^{14} \mathrm{C}-1$ & 12,370 & \pm 60 & $14,770-14,082$ & 14,426 & KIA 25339 \\
\hline & 1 & BAR-IW- $-{ }^{14} \mathrm{C}-3$ & 11,700 & \pm 100 & $13,761-13,338$ & 13,550 & KIA 33159 \\
\hline & 1 & BAR-IW- ${ }^{14} \mathrm{C}-5$ & 11,310 & \pm 45 & $13,275-13,107$ & 13,191 & KIA 25656 \\
\hline & 2 & BAR-IW- ${ }^{14} \mathrm{C}-7$ & 10,740 & \pm 60 & $12,861-12,681$ & 12,771 & KIA 25657 \\
\hline & 2 & BAR-IW- ${ }^{14} \mathrm{C}-11$ & 10,480 & \pm 65 & $12,690-12,141$ & 12,416 & KIA 25658 \\
\hline & 2 & BAR-IW- ${ }^{14} \mathrm{C}-22$ & 10,290 & \pm 45 & $12,367-11,830$ & 12,099 & KIA 25659 \\
\hline & 1 & BR06-IW-3.5 & 9850 & $+230 /-220$ & $12,098-10,585$ & 11,342 & KIA 33155 \\
\hline & 2 & BR06-IW-3.11 & 9990 & \pm 80 & $11,811-11,238$ & 11,525 & KIA 33156 \\
\hline & 1 & BR06-IW-4.1 & 11,250 & \pm 90 & $13,284-12,956$ & 13,120 & KIA 33157 \\
\hline & 2 & BR06-IW-4.9 & 10,730 & \pm 60 & $12,857-12,674$ & 12,766 & KIA 33158 \\
\hline
\end{tabular}




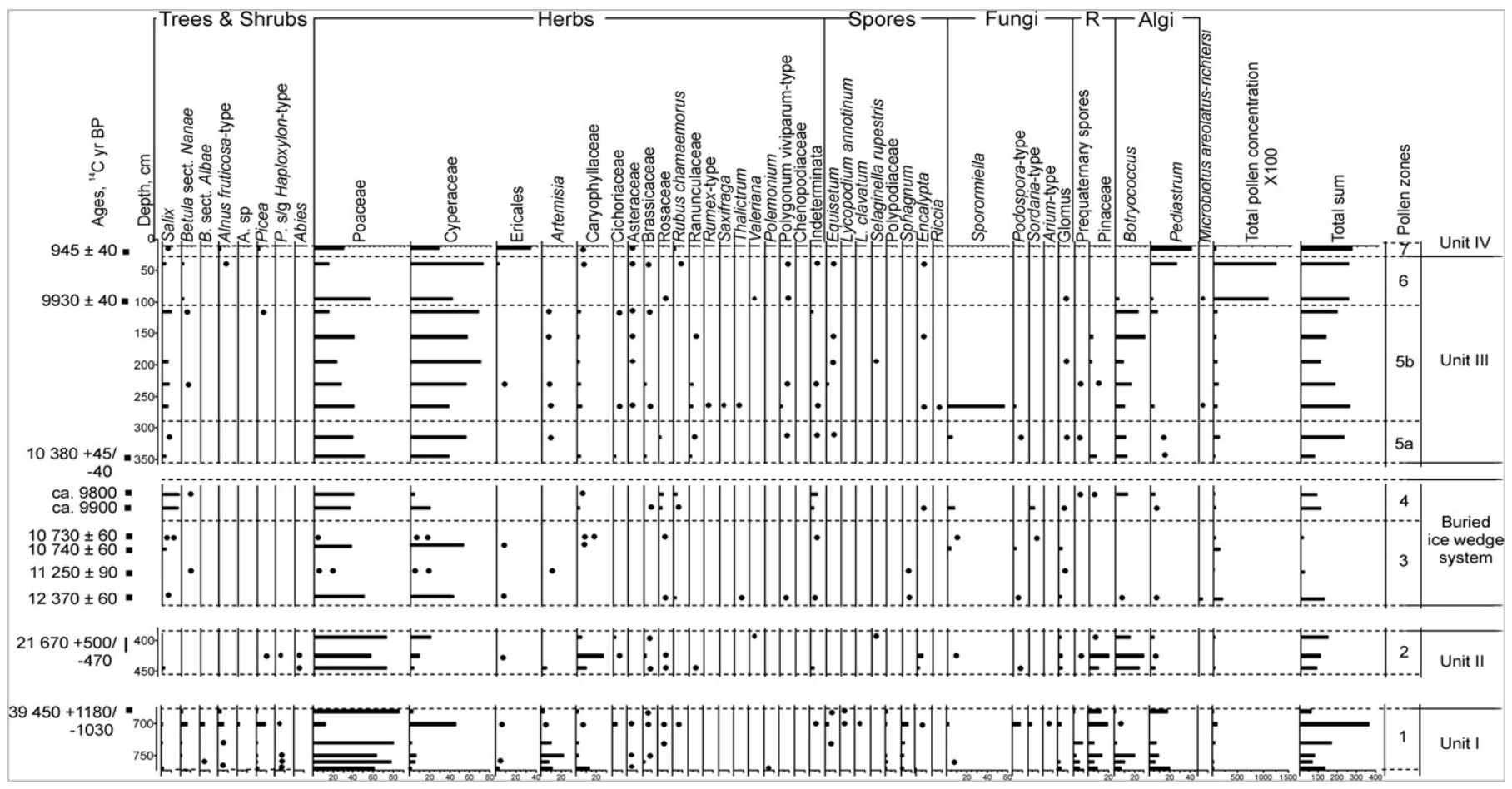

Fig. 7. Pollen spectra of the Barrow permafrost tunnel sequence (frozen sediments and ice wedges).

PZ-2 (unit II) is dominated by Poaceae with some Cyperaceae, Caryophyllaceae, and Asteraceae pollen pointing to prevailing open grass communities (Fig. 7). The total pollen concentration is very low (up to 1500 grains $\mathrm{g}^{-1}$ ). High amounts of green algae colonies (Pediastrum and Botryoccous) and relatively high amounts of reworked Pinaceae and Tertiary spores are also characteristic. The uppermost sample from the zone is dated to about $21.7 \mathrm{kyr}$ BP (Table 1) suggesting LW age of the PZ-2 spectra. The climate was cold and dry although the presence of green algae colonies (up to 25\%) suggests that sedimentation was in shallow water conditions at least during short intervals. LW pollen records from northern Alaska (e.g. Anderson et al., 1988; Eisner and Colinvaux, 1992 and references therein) also reflect mostly treeless environment.

Rare findings of freshwater ostracods have been observed in one sample from the upper part of unit II. In particular, fragments and juvenile valves of freshwater Candoninae species have been found as well as valves of female specimen of Limnocythere inopinata (BAIRD, 1843). The latter tolerates a wide range of environmental conditions inhabiting also saline inland waters (e.g. Yin et al., 1999) and brackish coastal waters (e.g. Frenzel and Viehberg, 2004). Additionally, marine foraminifera (planktic species Neogloboquadrina pachyderma sinistral (s)) and benthic species Epistominella exigua and Alabaminella weddelensis were found in samples of the units I and II.

Pollen spectra from the ice-wedge samples dated to about 12.4 kyr BP (PZ-3) are characterized by higher pollen concentration $\left(27,000\right.$ grains $\left.^{-1}\right)$ and larger amount of Cyperaceae, Rosaceae, and Rubus chamaemorus pollen (Fig. 7). Sedge and grass plant communities dominated around the site during this time. Climate conditions were warmer and wetter than during the LW.

Other ice-wedge pollen spectra of PZ-3 dated to about $10.7 \mathrm{kyr}$ $\mathrm{BP}$ are characterized by a larger amount of Salix pollen reflecting further climate warming. The spectra are rather similar to a pollen spectrum from a $10.5 \mathrm{kyr}$ BP old peat sample from Point Barrow (Colinvaux, 1964), although that spectrum contains more Salix pollen, which may be indicative of warmer climate at about
$10.5 \mathrm{kyr}$ BP and/or with local environments at the sites. We assume that low-shrub willow and sedge and grass communities dominated the local vegetation at about 10.7-10.5 kyr BP. Rather large amounts of the dung-inhabiting Sordariales (Sporormiella and Podospora) fungi spores found in the $10.7 \mathrm{kyr}$ BP old samples can be seen as indication of herbivores grazing in the area at the Lateglacial to Holocene transition (Van Geel, 2001 and references therein). Generally, pollen spectra from the buried ice-wedge system point to warmer summer conditions than before and may reflect the Bølling-Allerød interstadial.

Pollen spectra from the ice-wedge samples dated to about 10.0-9.9 kyr BP (PZ-4) are characterized by higher amounts of Salix, Rosaceae, and Rubus chamaemorus pollen. Higher amounts of Equisetum and Encalypta spores point to disturbed soils at the site. Large amounts of the dung-inhabiting fungi spores again point to the presence of grazing mammals in the area.

Pollen spectra of PZ-5 from a buried cryosol of unit III dated to about 10.4-9.9 kyr BP show relatively low pollen concentrations (up to 10500 grains $\mathrm{g}^{-1}$ ) and large amounts of Botryococcus colonies. The pollen spectra from the lower subzone PZ-5a contain less shrub pollen (Salix) than in spectra from the PZ-5b. Lower Salix pollen content in PZ-5a may reflect severe climate conditions such as in the YD. However, this assumption is based on only one sample, thus, YD is likely pronounced weakly. A large peak of the Sporormiella fungi spores at the bottom of PZ-5b reflects a presence of grazing herds in the area at the Preboreal onset of the Holocene (Van Geel, 2001 and references therein). Shrub willow and sedge and grass communities dominated the vegetation during the PB interval. Climate conditions were relatively warm.

A high number of testate amoebae shells were found in two samples of PZ-5 (unit III) in $3.15 \mathrm{~m}$ and $1.15 \mathrm{~m}$ depth. Shells of testate amoebae are very fragile; therefore their presence reflects autochthonous accumulation without any additional reworking. However, many of the samples do not contain any shells. The total number of shells ( 73 specimens) represents eight species (Table 2 ). They are dominantly eurybiotic and soil taxa typical for pioneer 
Table 2

Rhizopod distribution in the Barrow sediment sequence. The grey-shaded areas underline the two samples, where rhizopods could be identified.

\begin{tabular}{|c|c|c|c|c|c|c|c|c|c|c|c|c|}
\hline Sample ID & $\begin{array}{l}\text { Depth } \\
\text { [m] }\end{array}$ & $\begin{array}{l}\text { Centropyxis } \\
\text { aerophila }\end{array}$ & $\begin{array}{l}\text { C. constricta } \\
\text { v. minima }\end{array}$ & C. orbicularis & C. plagiostoma & C. sylvatica & $\begin{array}{l}\text { C. sylvatica } \\
\text { v. minor }\end{array}$ & $\begin{array}{l}\text { Cyclopyxis } \\
\text { kahli }\end{array}$ & $\begin{array}{l}\text { C. eurystoma } \\
\text { v. parvula }\end{array}$ & $\begin{array}{l}\text { Plagiopyxis } \\
\text { minuta }\end{array}$ & $\begin{array}{l}\mathcal{N} \cong \text { of } \\
\text { specimens }\end{array}$ & $\begin{array}{l}\mathcal{N} \cong \text { of } \\
\text { species }\end{array}$ \\
\hline BAR-1/1 & 0.15 & 0 & 0 & 0 & 0 & 0 & 0 & 0 & 0 & 0 & 0 & 0 \\
\hline BAR-1/2 & 0.4 & 0 & 0 & 0 & 0 & 0 & 0 & 0 & 0 & 0 & 0 & 0 \\
\hline BAR- $1 / 3$ & 0.95 & 0 & 0 & 0 & 0 & 0 & 0 & 0 & 0 & 0 & 0 & 0 \\
\hline BAR- $1 / 4$ & 1.15 & 0 & 4 & 1 & 1 & 6 & 17 & 7 & 0 & 0 & 36 & 6 \\
\hline BAR-1/5 & 1.55 & 0 & 1 & 0 & 0 & 0 & 0 & 0 & 0 & 1 & 2 & 2 \\
\hline BAR-1/6 & 1.95 & 0 & 0 & 0 & 0 & 0 & 0 & 0 & 0 & 0 & 0 & 0 \\
\hline BAR-1/10 & 2.3 & 0 & 0 & 0 & 0 & 0 & 0 & 0 & 0 & 0 & 0 & 0 \\
\hline BAR- $1 / 7$ & 2.65 & 0 & 1 & 0 & 0 & 0 & 0 & 0 & 0 & 0 & 1 & 1 \\
\hline BAR- $1 / 8$ & 3.15 & 3 & 12 & 2 & 0 & 5 & 9 & 0 & 2 & 0 & 33 & 6 \\
\hline BAR-1/9 & 3.45 & 0 & 1 & 0 & 0 & 0 & 0 & 0 & 0 & 0 & 1 & 1 \\
\hline BAR-1/11 & 3.95 & 0 & 0 & 0 & 0 & 0 & 0 & 0 & 0 & 0 & 0 & 0 \\
\hline BAR-1/12 & 4.25 & 0 & 0 & 0 & 0 & 0 & 0 & 0 & 0 & 0 & 0 & 0 \\
\hline BAR- $1 / 13$ & 4.45 & 0 & 0 & 0 & 0 & 0 & 0 & 0 & 0 & 0 & 0 & 0 \\
\hline
\end{tabular}

colonization of disturbed soils. Only Centropyxis plagiostoma that was found in one sample is a calcareous taxa pointing to favorable conditions for soil development.

Pollen spectra from a peat lens in the lower part of unit III dated to about 9.9 kyr BP (PZ-6) are characterized by a very high pollen concentration (up to 122,000 grains $\mathrm{g}^{-1}$ ) reflecting a dense vegetation cover and a warming of the climate at the beginning of the Holocene. Sedge and grass communities dominated the vegetation, although the presence of Betula sect. Nanae pollen reflects that dwarf birch might have been present on the site. The uppermost spectrum of the PZ-6 is comparable with a spectrum from a $9.5 \mathrm{kyr}$ BP old peat sample in the tunnel site (Colinvaux, 1964). Higher Salix and Betula sect. Nanae pollen contents in this spectrum indicate probably warmer climate conditions at the onset of the Preboreal warming.

The uppermost pollen spectrum of PZ-7 (unit IV) dated to $0.95 \mathrm{kyr}$ BP is characterized by large amounts of Ericales, Poaceae, and Cyperaceae pollen and a relatively low pollen concentration ( 4300 grains $\mathrm{g}^{-1}$ ). The vegetation cover was probably similar to the modern tussock tundra dominated by Eriophorum vaginatum with rich assemblages of associated species including ericaceous taxa such as Vaccinium vitis-idea, Vaccinium uliginosum and Ledum decumbens. However, the modern vegetation of the area mostly consists of sedge-grass meadows with few other vascular species such as Potentilla hyparctica, Luzula confusa and Salix rotundifolia (Brown et al., 1980).

\subsection{Studies of ground ice}

\subsubsection{Stable isotopes in ice wedges}

The application of $\mathrm{O}$ and $\mathrm{H}$ isotopes for paleoclimatic studies in ice wedges is used for reconstructing winter temperature trends
(Mackay, 1983; Vaikmäe, 1989; Vasil'chuk, 1992, 2006; Vasil'chuk et al., 2000; Meyer et al., 2002a, b). Ice wedges are formed by repeated frost cracking and percolation of melt water of winter snow into frost cracks, forming ice veins. Since frost cracking occurs in winter and filling of frost cracks in general in early summer during snow melt (Mackay, 1974), single ice veins of an ice wedge contain a discrete stable isotope signal of the snow from the preceding winter.

Two intersecting ice wedges were distinguished in the tunnel by means of their orientation of ice structures (Fig. 4), which are likely related to two different directions of polygonal frost cracking. In the western part of the tunnel, $\mathrm{E}-\mathrm{W}$ oriented foliation predominates, whereas in the eastern part $\mathrm{N}-\mathrm{S}$ orientation is observed. The intersection area of the two ice wedges was difficult to determine, but observed near the new access shaft (about $5 \mathrm{~m}$ from lateral contact A; Fig. 4). Both, the upper contact between ice wedge and sediment as well as the lateral contacts of the ice wedges to the adjacent sediment in the western part of the tunnel were studied and sampled in detail.

In Table 3, hydrogen and oxygen isotope minimum, mean, and maximum values, standard deviations, slopes and intercepts in the $\delta^{18} \mathrm{O}-\delta D$ diagram (Fig. 8) are given for the two ice wedges and for the texture (segregated) ice. For comparison, stable isotopic compositions of recent snow, ice crystal and brine water are presented. The weighted mean annual isotope composition of precipitation at Barrow is $\delta^{18} \mathrm{O}=-18.7 \%, \delta D=-141 \%$ and $d$ excess $=6.3 \%$, respectively (IAEA, 2006).

The isotopic composition of ice wedges ranges between $-27.2 \%$ and $-21.1 \%$ for $\delta^{18} \mathrm{O}$ and from $-209 \%$ to $-161 \%$ for $\delta D$ (Fig. $8 \mathrm{a}$ ). The $d$ excess varies from $0.6 \%$ to $12.2 \%$ with a mean value of $7.2 \%$. In the co-isotope diagram, two clusters of ice wedge samples clearly

Table 3

Summary of stable isotope $\left(\delta^{18} \mathrm{O}, \delta D\right.$ and $d$ excess) minimum, mean and maximum values, standard deviations (sd) and slopes and intercepts from the $\delta^{18} \mathrm{O}-\delta D$ diagram for the sampled ice wedges, texture ice and for recent snow at Barrow. Additionally, data from the upper ice-wedge contact with the sediment, from the brine underneath the ice wedge and from ice crystals are given here.

\begin{tabular}{|c|c|c|c|c|c|c|c|c|c|c|c|c|c|c|c|c|c|}
\hline \multirow[t]{2}{*}{ Sample type } & $N$ & $\begin{array}{l}\text { Depth } \\
\text { [m] }\end{array}$ & $\begin{array}{l}\delta^{18} \mathrm{O} \\
{[\%]} \\
\end{array}$ & $\begin{array}{l}\delta^{18} \mathrm{O} \\
{[\%]} \\
\end{array}$ & $\begin{array}{l}\delta^{18} \mathrm{O} \\
{[\%]}\end{array}$ & $\begin{array}{l}\delta^{18} \mathrm{O} \\
{[\% \mathrm{o}]}\end{array}$ & $\begin{array}{l}\delta D \\
{[\%]} \\
\end{array}$ & $\begin{array}{l}\delta D \\
{[\%]}\end{array}$ & $\begin{array}{l}\delta D \\
{[\%]}\end{array}$ & $\begin{array}{l}\delta D \\
{\left[\%{ }^{\circ}\right]} \\
\end{array}$ & $\begin{array}{l}d \\
{[\%]}\end{array}$ & $\begin{array}{l}d \\
{[\%]}\end{array}$ & $\begin{array}{l}d \\
{[\%]}\end{array}$ & $\begin{array}{l}d \\
{[\%]} \\
\end{array}$ & Slope & Intercept & $R^{2}$ \\
\hline & & & Min & Mean & Max & Sd & Min & Mean & Max & Sd & Min & Mean & Max & Sd & & & \\
\hline Both ice wedges & 121 & 4.5 & -27.2 & -24.4 & -21.1 & 1.8 & -209.4 & -187.6 & -160.8 & 13.3 & 0.6 & 7.2 & 12.2 & 2.2 & 7.4 & -7.6 & 0.98 \\
\hline $\begin{array}{l}\text { Ice wedge } \\
\text { cluster } 1\end{array}$ & 56 & 4.5 & -23.9 & -22.6 & -21.1 & 0.8 & -188.2 & -174.8 & -160.8 & 6.3 & 0.6 & 6.1 & 10.5 & 2.2 & 7.8 & 1.1 & 0.88 \\
\hline $\begin{array}{l}\text { Ice wedge } \\
\text { cluster } 2\end{array}$ & 65 & 4.5 & -27.2 & -25.9 & -24.5 & 0.7 & -209.4 & -198.9 & -189.6 & 4.9 & 2.3 & 8.2 & 12.2 & 1.6 & 7.2 & -13.0 & 0.91 \\
\hline $\begin{array}{l}\text { Ice wedge - } \\
\text { upper contact }\end{array}$ & 7 & $3.6-3.7$ & -24.1 & -21.8 & -19.5 & 1.7 & -189.1 & -174.8 & -159.3 & 10.9 & -3.5 & -0.4 & 3.7 & 2.6 & 6.5 & -33.4 & 1.00 \\
\hline Texture ice & 15 & Variable & -20.1 & -16.7 & -13.9 & 2.1 & -158.2 & -135.4 & -111.1 & 15.7 & -12.0 & -1.6 & 5.2 & 5.8 & 6.9 & -19.2 & 0.88 \\
\hline Snow & 18 & $0-2.8$ & -33.2 & -28.7 & -19.6 & 3.3 & -247.3 & -216.6 & -146.7 & 25.8 & 9.1 & 13.0 & 18.1 & 3.1 & 7.8 & 6.2 & 0.99 \\
\hline Ice Crystal & 2 & - & -22.5 & -22.3 & -22.1 & - & -170.6 & -169.6 & -168.5 & - & 8.8 & 9.2 & 9.6 & - & - & - & - \\
\hline Brine & 1 & 7.0 & - & -19.5 & - & - & - & -162 & - & - & - & -5 & - & - & - & - & - \\
\hline
\end{tabular}



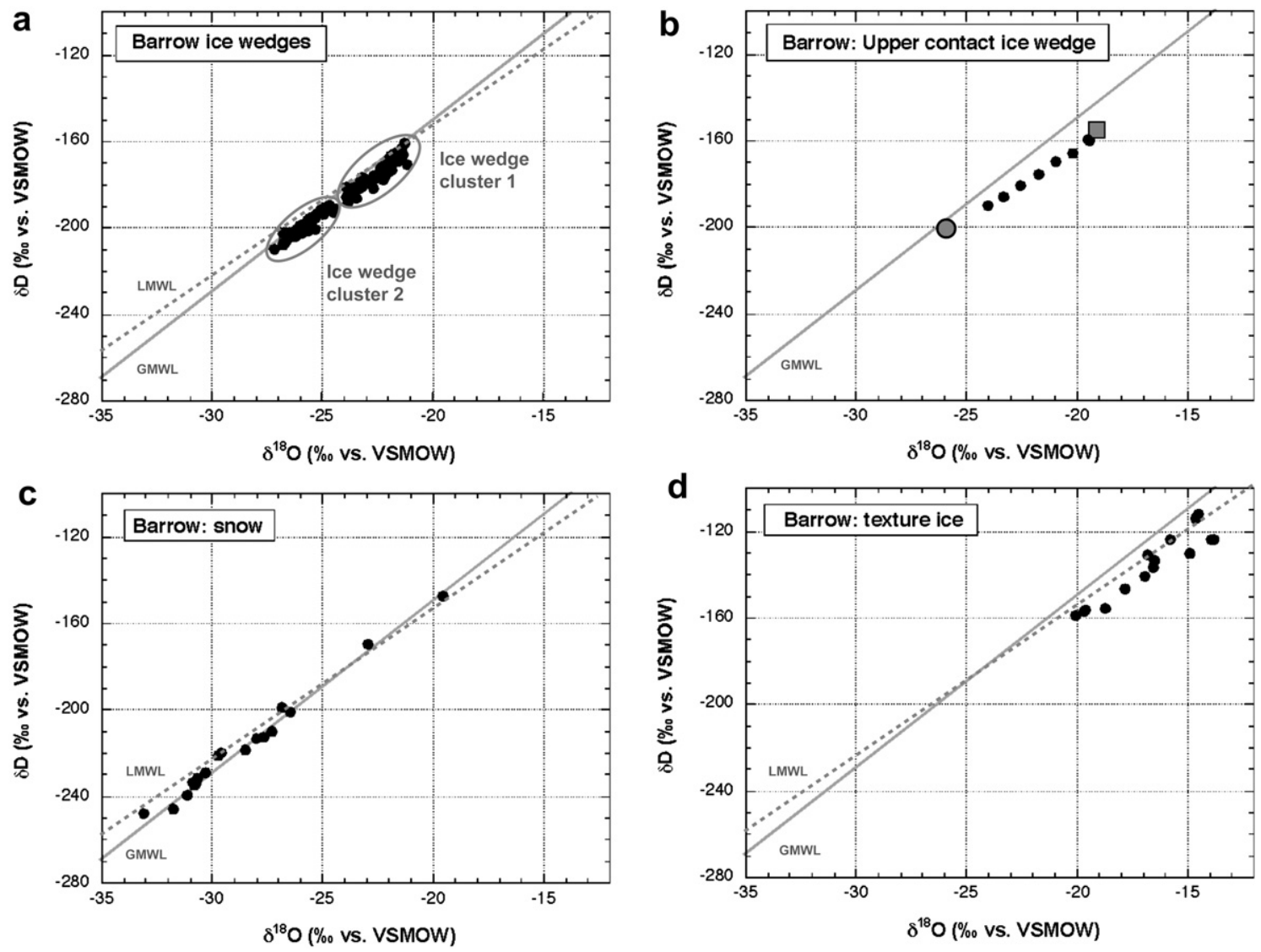

Fig. 8. $\delta^{18} \mathrm{O}-\delta D$ diagrams for Barrow: (a) ice wedges $\left(\delta^{18} \mathrm{O}>-24.4 \%\right.$ isotope cluster $1 ; \delta^{18} \mathrm{O}<-24.4 \%$ isotope cluster 2 ), (b) upper contact of ice wedge with overlying sediment (compare Fig. 10). A grey dot shows the mean $\delta^{18} \mathrm{O}$ of the underlying wedge ice (endmember 1 ; ice wedge cluster 2 ); a grey square displays the $\delta^{18} \mathrm{O}$ of texture ice (endmember 2 ; $0.05 \mathrm{~m}$ above the contact); (c) snow, (d) texture ice. GMWL is the Global Meteoric Water Line. LMWL is the Local Meteoric Water Line from Barrow (IAEA, 2006).

separated from each other can be distinguished: cluster 1 with heavier $\left(\delta^{18} \mathrm{O}\right.$ mean of $-22.6 \% ; \delta D$ mean of $-175 \%$ ) and cluster 2 with lighter $\left(\delta^{18} \mathrm{O}\right.$ mean of $-25.9 \%$; $\delta D$ mean of $-199 \%$ ) isotopic composition (Fig. 8a). The boundary between these two, isotopically different types of ice is defined at $-24.4 \%$ in $\delta^{18} \mathrm{O}$, which is the mean value of all ice-wedge samples. This boundary can be detected at about $2.5 \mathrm{~m}$ from the lateral contact near $A$ and $E$ as well as about $1 \mathrm{~m}$ from $\mathrm{C}^{\prime}$ in the sampling transects (Fig. 9). A peculiarity is the occurrence of four samples with $\delta^{18} \mathrm{O}$ heavier than $-24.4 \%$ (thus belonging to cluster 1) at transect $\mathrm{B}-\mathrm{B}^{\prime}$ in the central part of the ice wedge. Both isotope clusters show relatively constant stable isotopic composition with variations, in general, of less than $4 \%$ for $\delta^{18} \mathrm{O}$ and $30 \%$ for $\delta D$, respectively. Both clusters are situated slightly underneath the GMWL (Fig. 8a) with similar mean $d$ excess values of $6.2 \%$ and $8.2 \%$. Generally, the heavier the isotopic composition, the lower the $d$ excess. The boundary between isotope clusters is not in the intersection area of the two ice wedges, thus not controlled by the structure of the ice-wedge system. Therefore, it can be assumed as climate-relevant (Meyer et al., 2002a, b).

The general trend in sampling transects $A-A^{\prime}, C-C^{\prime}$ and $E-E^{\prime}$ is similar from the lateral contact to the middle part of the ice wedges (Fig. 9). Heaviest (most positive) isotopic composition is observed near the contact of ice wedge and sediment. At about a distance of $0.3 \mathrm{~m}$ from the lateral contacts, $\delta^{18} \mathrm{O}$ decreases to about -24 to $-23 \%$, before increasing again to about $-22 \%$. From this maximum, a continuous decrease of $\delta^{18} \mathrm{O}$ to the most negative values around $-27 \%$ is observed. A relatively smooth transition from heaviest to lightest isotopic composition is found in transect $A-A^{\prime}$, whereas in transect $C-C^{\prime}$ this transition is more abrupt. From the minima in $\delta^{18} \mathrm{O}$, a slight rise of the isotopic composition to about $-26 \%$ and $-25 \%$ is found in all transects, with some excursions to higher $\delta^{18} \mathrm{O}$ up to $-23 \%$ (e.g. in transect $\mathrm{B}-\mathrm{B}^{\prime}$ ).

The ice sampled in transect $A-A^{\prime}$ was formed from 12.4 to $10.3 \mathrm{kyr}$ BP (corresponding to $14.8-11.8 \mathrm{kyr}$ cal BP; Table 1). Continuous growth from the east to the west side is assumed for transect $A-A^{\prime}$ since a sequence of five AMS radiocarbon dates of ice-included organic matter shows decreasing ages with increasing distance from the lateral contact (without age reversals; Fig. 9). This continuous sequence of ice-wedge isotope composition may be used as winter temperature indicator for the Lateglacial-Early Holocene transition.

At the upper contact of the ice wedge to the sediment (Fig. 3), a decrease in $\delta \mathrm{D}$ (from about $-160 \%$ to $-190 \%$ ) and in $\delta^{18} \mathrm{O}$ (from about $-19 \%$ to $-24 \%$ ) as well as an increase in $d$ excess (from $-3.5 \%$ to $3.7 \%$ ) is found (Table 4 and Fig. 10). These isotope data from the interface sediment - top of ice wedge range well between the endmembers (Table 3 ) texture ice $\left(\delta^{18} \mathrm{O}=-19 \%\right.$; sample was taken $0.05 \mathrm{~m}$ above the ice wedge-sediment contact, dated to about $10.4 \mathrm{kyr} \mathrm{BP}$ ) and ice-wedge ice (mean $\delta^{18} \mathrm{O}$ of isotope cluster 2 is $-25.9 \%$; $0.5 \mathrm{~m}$ below the contact, dated to 10.7 to $10.3 \mathrm{kyr} \mathrm{BP}$ ). In the $\delta^{18} \mathrm{O}-\delta D$ diagram (Fig. $8 \mathrm{~b}$ ), the samples from the contact display a linear relationship with a slope of 6.5 and a $R^{2}$ of $1.00(N=7)$.

\subsubsection{Stable isotopes and hydrochemistry in texture ice and pore} water

When the water volume of thawed texture ice was sufficient, the water was studied for hydrochemical and stable isotope composition. Texture ice in the permafrost deposits shows a much heavier 

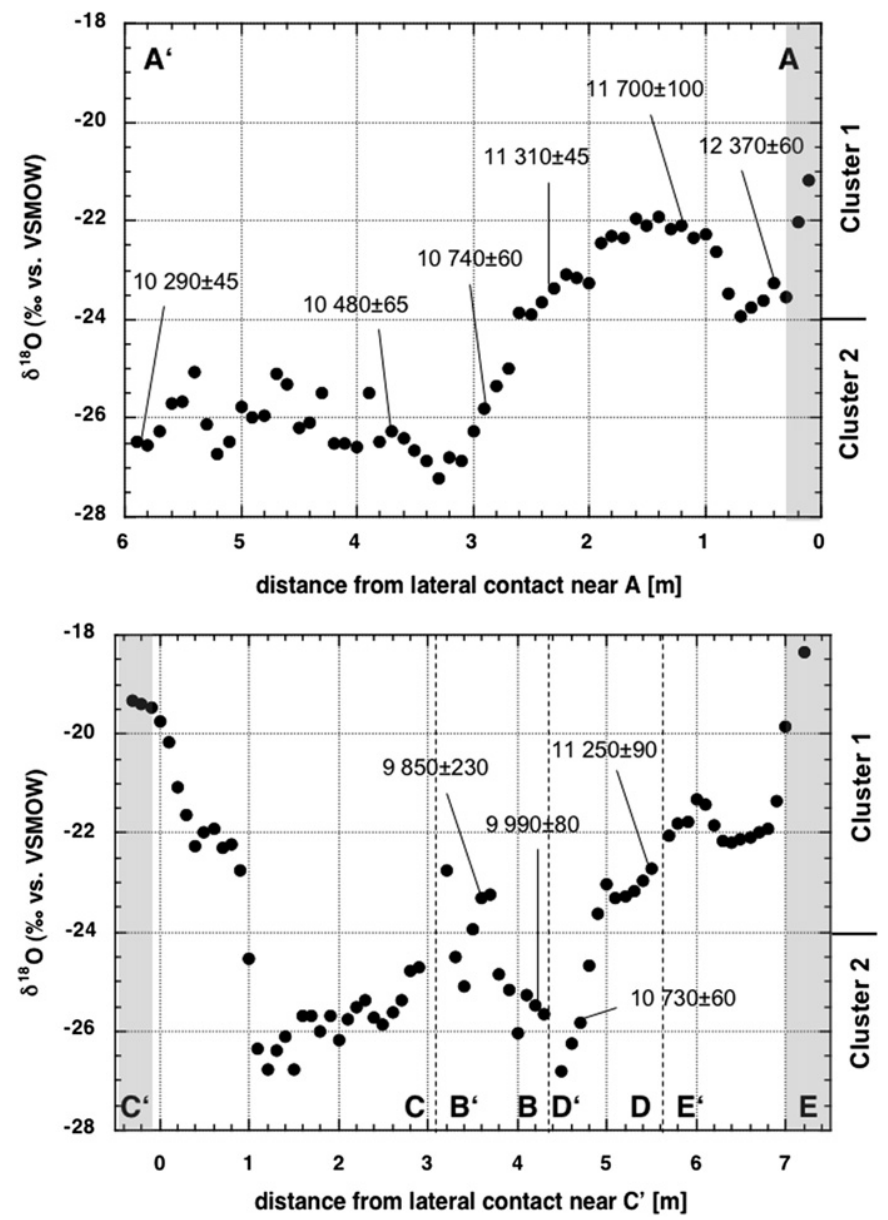

Fig. 9. Oxygen isotope profiles for two horizontal sampling transects $\left(A-A^{\prime}\right.$ and $C^{\prime}-E$, compare Figs. 3 and 4) as function of the distance from the lateral contact of the ice wedge with the adjacent sediments. Shaded areas mark samples within sediments. Numbers indicate exact position of radiocarbon AMS-dated organic matter in ice wedges (in yr BP, see Table 1).

isotopic composition than the ice-wedge system (Fig. 8d), because it represents a mixture of summer and winter precipitation (Vaikmäe, 1989) with a mean isotopic composition of $-17.5 \%$ for $\delta^{18} \mathrm{O},-140 \%$ for $\delta D$ and $0.8 \%$ for the $d$ excess (Table 3; Fig. 11) and may also reflect soil and ground water that was present as initial freezing occurred. The stable isotope composition of texture ice shows a clear succession (Fig. 11) from lighter values in the lowest (salty) unit II $\left(\delta^{18} \mathrm{O}=-20.1 \%\right.$ o $\delta D=-158 \%$ ), to heavier $\delta$-values in unit III near the surface $\left(\delta^{18} \mathrm{O}=-14.5 \%\right.$, $\delta D=-111 \%$ o $)$.

The electrical conductivity of texture ice (as expression of the salt content) in the sedimentary profile increase towards the bottom of the tunnel and reaches values up to about $8000 \mu \mathrm{S} \mathrm{cm}^{-1}$ (corresponding to a salinity of $\sim 4.8 \%$, Fig. 11 ). Salty unfrozen pore solution

Table 4

Distance from the upper contact of the ice wedge with the overlying sediment with regard to a changing isotopic composition.

\begin{tabular}{lllll}
\hline Sample ID & $\begin{array}{l}\text { Distance from } \\
\text { top }[\mathrm{cm}]\end{array}$ & $\begin{array}{l}\delta D \\
{[\%]}\end{array}$ & $\begin{array}{l}\delta^{18} \mathrm{O} \\
{[\% \mathrm{o}]}\end{array}$ & $\begin{array}{l}d \text { Excess } \\
{[\% \text { oo }]}\end{array}$ \\
\hline BAR-IW-Contact-2-1 & $0-1$ & -159.3 & -19.5 & -3.5 \\
BAR-IW-Contact-2-2 & $1-2$ & -165.2 & -20.2 & -3.4 \\
BAR-IW-Contact-2-3 & $2-3$ & -169.3 & -21.0 & -1.0 \\
BAR-IW-Contact-2-4 & $3-4$ & -175.0 & -21.8 & -0.7 \\
BAR-IW-Contact-2-5 & $4-5$ & -180.1 & -22.6 & 0.6 \\
BAR-IW-Contact-2-6 & $5-6$ & -185.4 & -23.4 & 1.3 \\
BAR-IW-Contact-2-7 & $6-7$ & -189.9 & -24.1 & 3.7 \\
\hline
\end{tabular}

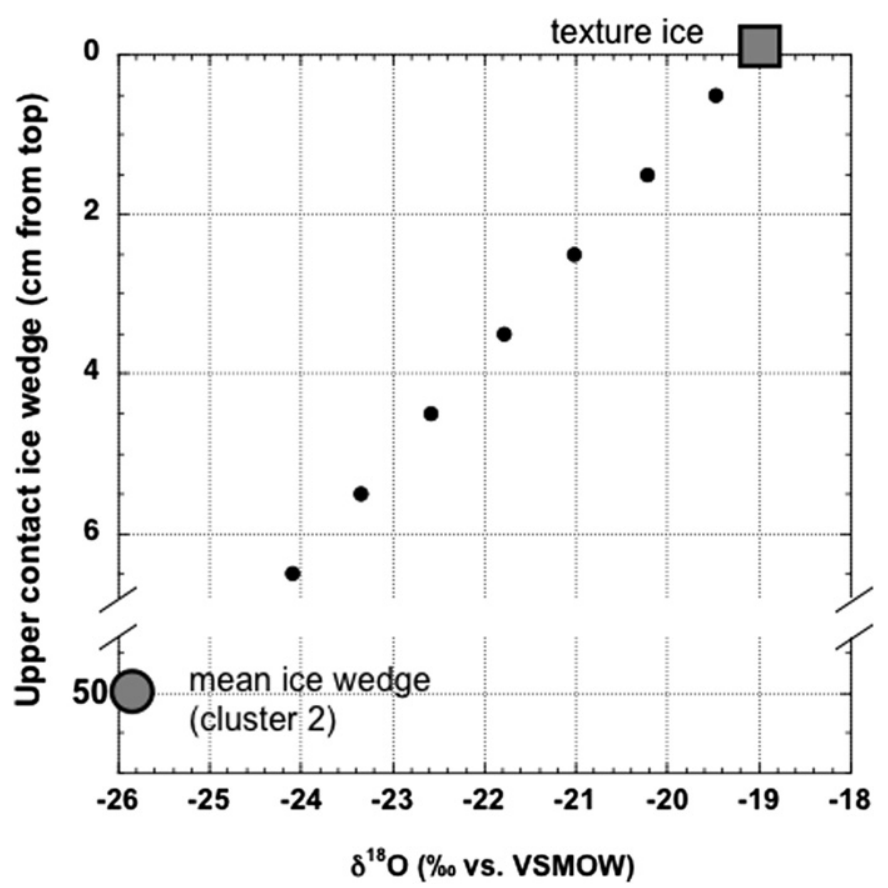

Fig. 10. Upper contact of the ice wedge. Black dots display the oxygen isotope profile versus distance from the interface ice wedge-sediment. A grey dot displays the mean $\delta^{18} \mathrm{O}$ of endmember 1 , the underlying wedge ice (from isotope cluster 2; $0.5 \mathrm{~m}$ below contact, age: $10.3-10.7 \mathrm{kyr} \mathrm{BP})$. A grey square $\delta^{18} \mathrm{O}$ represents the mean $\delta^{18} \mathrm{O}$ of endmember 2, texture ice sampled $0.05 \mathrm{~m}$ above contact ice wedge-sediment (age: 10.4 kyr BP).

(brine) from the underlying unit I was collected at about $7 \mathrm{~m}$ depth within the borehole B2 that shows an extremely high electrical conductivity of $119,800 \mu \mathrm{S} \mathrm{cm}^{-1}$ (salinity of $\sim 72 \%$ ) and an isotopic composition of $\delta^{18} \mathrm{O}=-19.6 \%$ and $\delta D=-162 \%$ ( $d$ excess $=-5.1 \%$ ). Brown (1969b) had previously reported similar high conductivity values at depths to $3 \mathrm{~m}$ below sea level.

\subsubsection{Stable isotopes in modern snow and ice}

The range of stable isotopes in precipitation reflects seasonal variations of condensation temperatures. As the main water source for ice wedge growth, snow samples may be useful to interpret the stable isotopic composition of ground ice. A total number of 18 samples was taken from a $3.6 \mathrm{~m}$ thick snowdrift associated with a snow fence near Barrow in 2004. The isotopic composition of recent snow samples is given in a $\delta^{18} \mathrm{O}-\delta D$ diagram for the nearby snowdrift (Fig. 8c). The mean isotopic composition of snow is $-28.7 \%$ for $\delta^{18} \mathrm{O}$ and $-217 \%$ for $\delta D$, with respective maximum and minimum values of $-19.6 \%$ and $-33.2 \%$ for $\delta^{18} \mathrm{O}$ as well as of $-147 \%$ and $-247 \%$ for $\delta D$ (Table 3 ). The $d$ excess of snow is highly variable between $9.1 \%$ and $18.1 \%$, with a mean $d$ of $13 \%$. The snow samples are linearly correlated in the $\delta^{18} \mathrm{O}-\delta D$ diagram with a slope of 7.8 and an intercept of $6.1\left(R^{2}=0.99\right.$; Fig. 8c). This corresponds well with the Global Meteoric Water Line (GMWL) and points to no significant alteration of the snow cover during winter 2003/2004. The mean isotopic composition is, however, not characteristic for the entire winter since sampling did not reach the bottom of the snowdrift and was carried out in April 2004; thus, the early snow and parts of the late snow are both missing and, by consequence, the mean isotopic composition tends to be too light. Only two late snow samples (from April 2004, uppermost $0.2 \mathrm{~m}$ of the snow cover) show $\delta^{18} \mathrm{O}$ higher than $-25 \%$.

Single ice crystals formed from air humidity were sampled in the access shaft in April 2004 and 2006. The stable isotopic composition is assumed to reflect the air humidity of $2003 / 2004\left(\delta^{18} \mathrm{O}=-22.1 \%\right.$ \% 

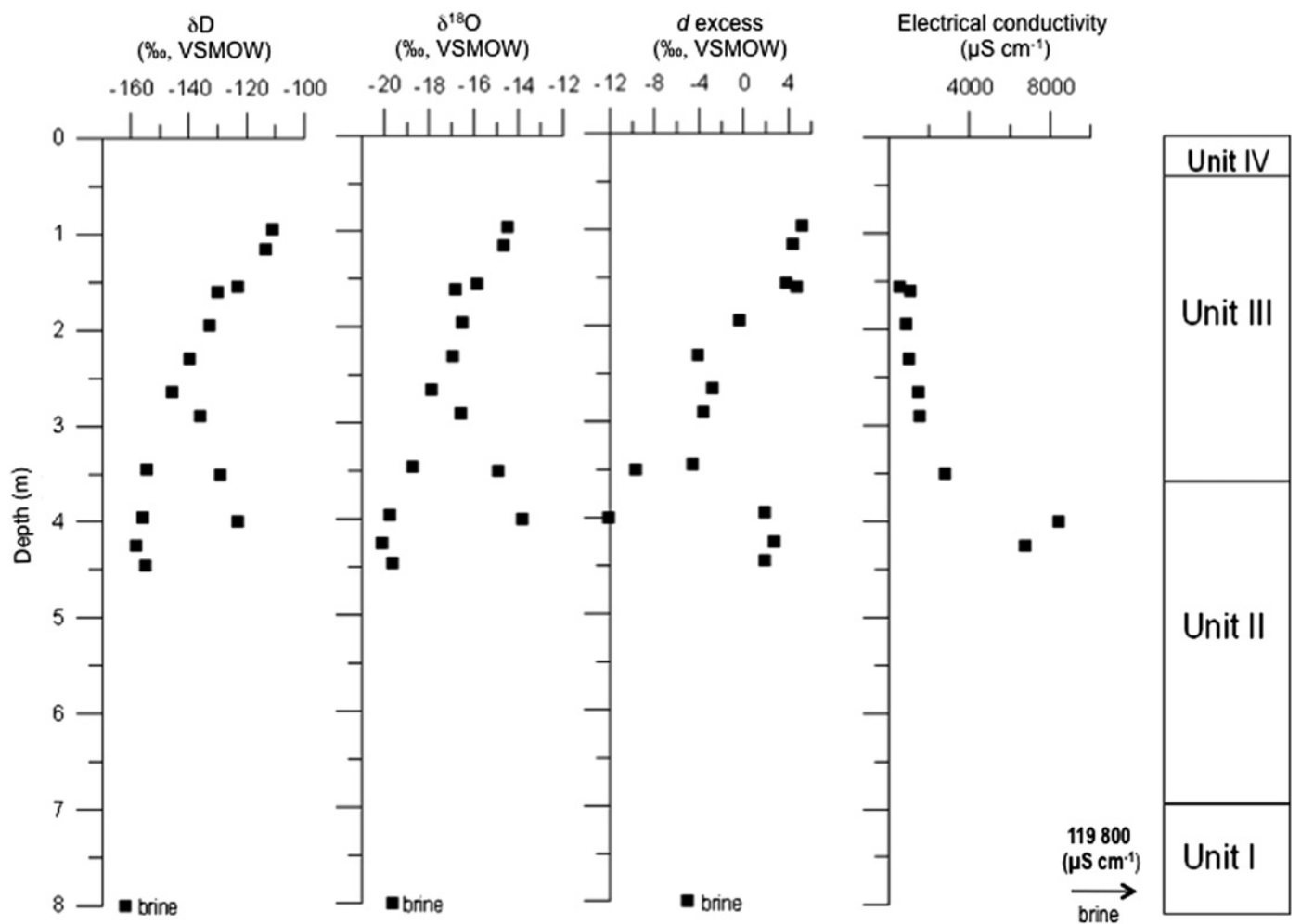

Fig. 11. Hydrochemical and stable isotope data of melted texture ice. The solid squares at a depth of $7.9 \mathrm{~m}$ display the (isotope) geochemical signature of the brine sample, which was taken at this depth (Unit I) from borehole B3 (compare Fig. 3). The electrical conductivity of the brine sample indicates hypersaline conditions (note: arrow).

$\delta D=-168.5 \%, d$ excess $=8.8 \%)$ and $2005 / 2006\left(\delta^{18} \mathrm{O}=-22.5 \%\right.$, $\delta D=-170.6 \%$ and $d$ excess $=9.6 \%$ ). Both crystals show similar isotopic composition (Table 3). Furthermore, their isotope signatures are comparable to the heaviest ice wedge and snow samples, thus rather reflecting a winter/spring signal of humidity, which is likely because the ice crystals were each formed in less than one year during the winter periods 2003/2004 and 2005/2006.

\subsection{Microbiological studies}

The buried ice-wedge system shows different methane concentrations of less than $1 \mathrm{nmol} \mathrm{g}^{-1}$ for ice wedge isotope cluster 1 and $20-70 \mathrm{nmol} \mathrm{g}^{-1}$ for ice wedge isotope cluster 2 (Fig. 12). This indicates different conditions for methane production during or after ice wedge growth. The wedge ice formed during the colder YD displays higher methane concentrations, whereas the warmer $A D$ wedge ice shows lower methane content.

The cell numbers of chemoorganotrophic bacteria (indicator for microbial population) in the sediments of unit III close to the ice wedges amounted to values between $3.3 \times 10^{3}$ and $5.3 \times 10^{6}$ cells $^{-1}$ sediment of the shaft, while the appropriate numbers of bacteria in sediments at the end of the tunnel (unit II) were only on the order of $10^{2}$ cells g ${ }^{-1}$ sediment. Methane production activity with and without additional substrate for methanogenic archaea was only detectable in the upper part of unit III to a depth of about $2.5 \mathrm{~m}$ (Table 5). The other samples that were analyzed did not indicate any methane production activities.

\section{Discussion}

\subsection{Paleoenvironmental and paleoclimate history}

The studied sediment and ground ice sequences were formed during the Lateglacial-Holocene transition and afterwards including LW, AD, YD, PB and Late Holocene intervals. The lower (Late Pleistocene) part as well as the upper (Holocene) part of the studied sediments both belong to the Barrow unit of the Gubik formation (Black, 1964; Sellmann and Brown, 1973).

According to the oldest radiocarbon dates between about 20 and $40 \mathrm{kyr} \mathrm{BP}$, we assign the deposits underlying and encompassing the ice-wedge system to the middle and late Wisconsin glacial stage. A geochronological gap of about 10000 years is

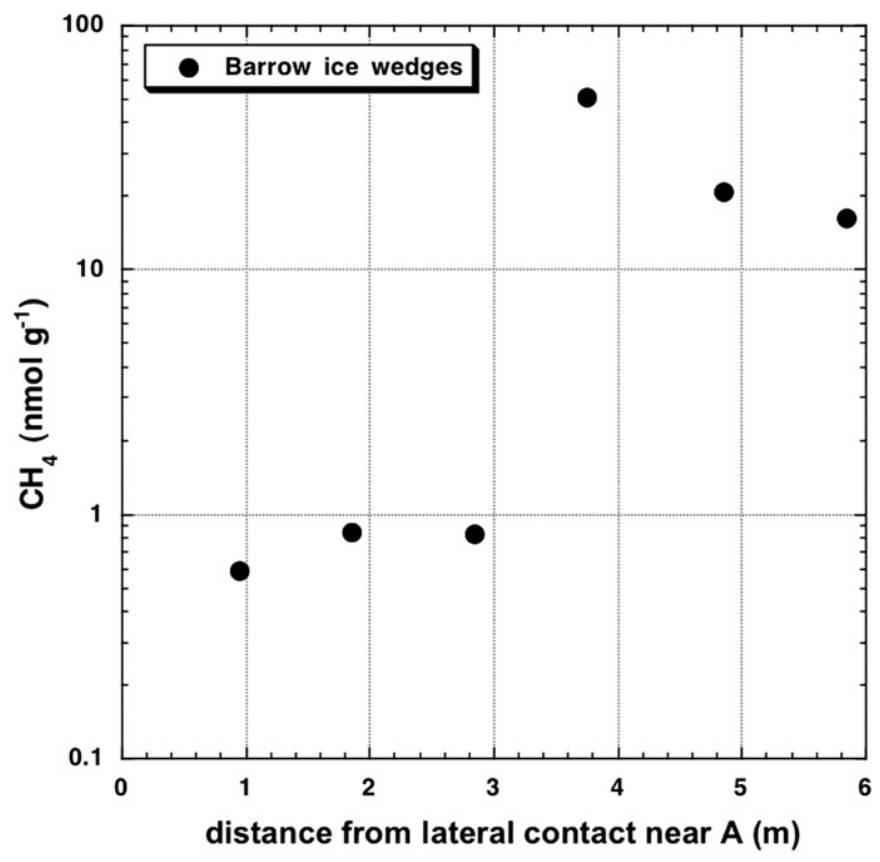

Fig. 12. Methane concentrations in the Barrow buried ice-wedge system. 
Table 5

$\mathrm{CH}_{4}$ production rate $\left[\mathrm{nmol} \mathrm{h}^{-1} \mathrm{~g}^{-1}\right]$ and methane production activities by chemoorganotrophic bacteria (COB) in sediment samples.

\begin{tabular}{lllll}
\hline Sample ID & $\begin{array}{l}\text { Depth } \\
{[\mathrm{m}]}\end{array}$ & $\begin{array}{l}\text { COB } \\
{\left[\text { cell counts }{ }^{-1}\right]}\end{array}$ & $\begin{array}{l}\text { Activity without } \\
\text { substrate }\end{array}$ & $\begin{array}{l}\text { Activity with } \\
\text { hydrogen }\end{array}$ \\
\hline Shaft & & & & \\
BAR-1/1 & 0.15 & $1.1 \times 10^{6}$ & 0.0046 & 0.0334 \\
BAR-1/2 & 0.4 & $1.4 \times 10^{6}$ & 0.0181 & 0.1503 \\
BAR-1/3 & 0.95 & $8.5 \times 10^{4}$ & - & - \\
BAR-1/4 & 1.15 & $1.0 \times 10^{6}$ & - & - \\
BAR-1/5 & 1.55 & $1.1 \times 10^{5}$ & 0.0014 & 0.002 \\
BAR-1/6 & 1.95 & $1.2 \times 10^{5}$ & - & - \\
BAR-1/10 & 2.3 & $1.7 \times 10^{5}$ & 0.0018 & - \\
BAR-1/7 & 2.65 & $3.3 \times 10^{3}$ & - & - \\
BAR-1/8 & 3.15 & $5.3 \times 10^{6}$ & - & - \\
BAR-1/9 & 3.45 & $5.2 \times 10^{6}$ & - & - \\
Lateral contact $($ near A) & & & - \\
BAR-1/11 & 3.95 & $1.5 \times 10^{2}$ & - & - \\
BAR-1/12 & 4.25 & $1.9 \times 10^{2}$ & - & - \\
BAR-1/13 & 4.45 & $4.7 \times 10^{2}$ & - & - \\
\hline
\end{tabular}

evident within the studied sedimentary sequence from ca 21.7 and 12.4 kyr BP between the sediment unit II and the overlying unit III based on the deposits mainly exposed in the access shaft. Deposition or subsequent reworking of the deposits between about $22 \mathrm{kyr}$ and $12 \mathrm{kyr}$ BP were not observed and, hence, we assume that the section remained frozen. A second gap of about 9000 years was found between unit III and the Late Holocene cover (unit IV), thus from ca 9.9 to $0.9 \mathrm{kyr}$ BP. Such gaps are not uncommon for perennially frozen sediments, since these sediments were frozen between intervening periods of deposition or cryoturbation activity.

The ice-wedge system developed epigenetically within LW deposits (units I, II) and about 10,000 years later (12.4-9.9 kyr BP) than these. The covering of about $2.5 \mathrm{~m}$ ice-rich deposits of unit III accumulated relatively quickly in some hundreds of years between 10.4 and $9.9 \mathrm{kyr}$ BP. The ice-wedge system was probably buried without reworking during the Lateglacial to Early Holocene transition sensu stricto. At this site, neither sedimentation nor ice-wedge growth is evident for the largest part of the Holocene, but large modern-day ice wedges occupy the land surface (Brown, 1967).

Sediment accumulation took place during the latest Holocene forming the uppermost part of the sequence up to the surface. This sequence accumulated under non-marine subaerial conditions, which is evident by three buried organic-rich layers and a secondary, buried ice wedge in unit III (Brown, 1965). This small diameter ice wedge suggests a short, intermediate interval of ice wedge development prior to present-day active layer development (Brown, 1967). The buried layers are generally attributed to cryoturbation processes and in this case associated with the formation and growth of ice wedges. An earlier hypothesis by Brown (1965) that the buried ice-wedge system was truncated by a thaw lake during the Early Holocene is not substantiated by the present sedimentary analyses. On top of the ice-wedge system, sediment from a rather local source accumulated and formed the 3-3.5 m thick permafrost section, which presently contains a system of large, active ice wedges associated with high-centered polygon relief.

Palynological results from the sedimentary sequence point to sparse grass-Artemisia dominated tundra-steppe vegetation, which occurred under variable summer climate and cold and dry conditions during the middle and late Wisconsin. The LGM is visible in the pollen spectra of PZ-2, even though shallow water bodies (e.g. polygonal ponds) existed near the site. Dense grass and sedge tundra vegetation grew under relatively warmer and wetter conditions during the $\mathrm{AD}$ interstadial. A further warming during the Bølling-Allerød is documented in a change of the vegetation to low-shrub tundra dominated by shrub willow and sedge-grass vegetation at about $10.7 \mathrm{kyr}$ BP. A decrease in shrub willow pollen at about 10.4 kyr BP may be interpreted as weakly pronounced YD cooling event. Shrub tundra with sedge-grass vegetation, shrub willow and dwarf birch dominated the vegetation during the PB onset of the Holocene at about $10 \mathrm{kyr}$ BP. Sedge-tussock tundra similar to the modern vegetation at the Barrow area dominated at about 0.9 kyr BP.

Palynological results from the buried ice-wedge system (PZ-3 and PZ-4) display similar Lateglacial to Early Holocene vegetation change than in the sedimentary sequence (PZ-5a and PZ-5b) with a clear warming trend at the onset of the PB. Those pollen samples from the ice wedges ${ }^{14} \mathrm{C}$-dated to the YD stadial do not reflect significantly colder conditions.

Different methane concentrations between both ice-wedge clusters confirm the subdivision of the ice-wedge system into two different types as suggested by the stable isotope data. The reason for the higher methane concentration in the colder YD period is unknown yet. However, microbiological studies in permafrost ecosystems of the Siberian Arctic showed that methanogenic archaea $\left(\mathrm{CH}_{4}\right.$-producing microorganisms) do not only survive in permafrost deposits, but also can be metabolically active in the frozen ground (Wagner et al., 2007). As these microorganisms are well-adapted to the cold permafrost conditions, the activity depends rather on other ecosystem variables such as the quality of organic matter than on the in-situ temperature. Therefore, the differences in methane concentrations can depend on the sedimentation processes of permafrost deposits or on different living conditions for the methane-producing microorganisms. However, low cell numbers and the absence of any methane production activity in the sediments of unit II, dated to about $21.7 \mathrm{kyr}$ BP, suggests that the conditions for microbial life were less favorable as compared to unit III, which is of YD to PB age.

\subsection{Texture ice and assumptions on the brine formation}

As a mixture of summer and winter precipitation (Vaikmäe, 1989), texture ice in the permafrost deposits displays a relatively heavy isotopic composition and low $d$ excess. The stable isotope values of texture ice show a clear succession (Fig. 11) from lighter isotopic composition in the lowest (salty) unit II to heavier values in unit III near the surface. This $\delta^{18} \mathrm{O}$ increase with decreasing depth could be rather related to an increase in mean air temperatures (e.g. from Late Pleistocene to Holocene times) than connected to an exchange with the highly saline sediments located below the icewedge system.

Since summer precipitation takes part in texture ice formation, the low $d$ excess may be explained with the participation of "recycled" (evaporated and reprecipitated) water from regional open water bodies or due to evaporation processes from polygonal ponds or the active layer. Additionally, isotope fractionation during texture ice formation (e.g. by slow freezing or repeated thaw-freeze cycles within the active layer) has to be taken into account. The $d$ excess varies strongly within the texture ice profile reaching minimum values in the lower part of the access shaft. This leads to the assumption that secondary fractionation processes (such as evaporation) were strongest with the onset of the sedimentation which buried the ice wedge.

Unfrozen and high saline pore water (brine) with extremely high electric conductivity of about $120 \mathrm{mS} \mathrm{cm}^{-1}$ occurs in unit I at about $7 \mathrm{~m}$ depth (borehole B2). For the Barrow area, highly concentrated pore waters in permafrost deposits 3-6 $\mathrm{m}$ below surface have already been described by Brown $(1963,1969 b)$ and O'Sullivan (1966) and explained by post-sedimentary freezing of 
marine deposits. Yoshikawa et al. (2004) reported saline water at $30 \mathrm{~m}$ depth in a borehole to the east of the site (Fig. 2). The brines occurring in the lowermost part of the studied permafrost section and relatively high ionic contents in the frozen parts in unit II indicate a marine influence during or after the sediment accumulation. However, the relatively light stable isotope composition $\left(\delta^{18} \mathrm{O}=-19.6 \% ; \delta D=-162 \%\right.$; Table 3$)$ suggests non-marine origin of the sampled pore water.

Since the electrical conductivity increases and $\delta^{18} \mathrm{O}$ and $\delta D$ decrease with the depth (Fig. 11), a marine origin of the water in the brines seems unlikely. In the case of a marine origin of the brine water, a heavier isotopic composition would be expected downwards (V-SMOW defined as $\delta^{18} \mathrm{O}=0 \%, \delta D=0 \%$ ). Even though highly saline samples measured with the equilibration method might be erroneous (Kohfahl et al., 2008), by up to $10 \%$ in $\delta D$ and $1 \%$ in $\delta^{18} \mathrm{O}$, these results suggest a non-marine origin of the brine water. Even though the resulting $d$ excess of brine water of $-5 \%$, (as a combination of $\delta^{18} \mathrm{O}$ and $\delta D$ ) should therefore be interpreted with caution, it is situated well underneath the GMWL, thus pointing to secondary fractionation (e.g. by evaporation) of meteoric water. The results are comparable to the mean isotopic composition of texture ice, but could also be related to other sources of water (e.g. ground and surface waters, as well as a mixture of various types of water). This is a substantial observation, because it leads to the assumption that water of non-marine origin was kept unfrozen and/or molten potentially due to the dissolution of formerly deposited marine salts. The unusual high salinity let us believe that salt expulsion during freezing seems unlikely to be the main process. The me-chanism leading to the formation of the brine is, however, unclear yet. In summary, pore water hydrochemical and stable isotope characteristics combined with the occurrence of fossil planktic and benthic marine foraminifera and brackish to fresh-water ostracods point to a lagoonal or estuarine environment similar to modern ones near Barrow. This assumption is substantiated by Faas (1966), who studied a Barrow paleo-estuary close to our site. Brackish conditions as assumed in an estuarine environment could be related to the Simpsonian transgression mentioned in Brigham (1985). Additionally, Fleischer et al. (1977) and Gat (1996) demonstrated that in continental areas, meteoric waters are able to replace marine brines, which are then characterized by high salinities and relatively light oxygen isotope composition.

\subsection{Winter precipitation and genetic implications for the buried ice-wedge system}

The absolute variations of $\delta D$ and $\delta^{18} \mathrm{O}$ within the co-isotope diagram of snow (Fig. 8c) certainly reflect variations of the winter temperatures. The Barrow LMWL has a significantly lower slope and intercept than the sampled snowdrift due to the fact that both, summer and winter precipitation have been used to calculate the LMWL (IAEA, 2006). When discarding the summer months with positive monthly air temperature from the calculations of the LMWL, a linear correlation between $\delta D$ and $\delta^{18} \mathrm{O}$ is similar to the GMWL and to our snow correlation (slope $=7.8$ ) in the $\delta^{18} \mathrm{O}-\delta D$ diagram, which is therefore used for the paleoclimate interpretation of the ice-wedge isotope data instead of the LMWL. The $d$ excess of single snow samples varies between two extremes (9 and $18 \%$ ). This leads to the assumption that at least two sources of water vapor are responsible to explain the high variability in $d$ excess of snow. Since all ice-wedge samples are located in the coisotope diagram between the isotopically heaviest and lightest snow sample (Fig. 8a, c), they might be genetically correlated and, thus, serve as the basis for interpretation of past winter temperatures.
The buried ice-wedge system comprises the Lateglacial including the Bølling-Allerød interstadial, Younger Dryas stadial as well as the Preboreal. A continuous ice wedge growth from the lateral contact with the sediment to the younger middle part of the ice wedges is concluded based on the observed sequence of AMSdated samples. The stable isotope data indicates the intersection of two, isotopically different, ice wedge clusters, which were formed in the mentioned time interval. Relatively heavy isotopic composition has been derived for stable isotope cluster 1 , dated to 12.4-11.3 kyr BP and to around $9.9 \mathrm{kyr}$ BP. The isotope cluster 1 should be mostly indicative for the Bølling-Allerød interstadial and for presumably warmer winter temperatures at that time. The interval between 10.7 and $10.0 \mathrm{kyr} \mathrm{BP}$ is characterized by lighter isotopic composition (isotope cluster 2), thus colder winter temperatures are reflected for the YD event. The central part of the ice wedge at transect B- $\mathrm{B}^{\prime}$ was dated 10.0-9.9 kyr BP, and a heavier isotopic composition is found, (again isotope cluster 1) potentially indicative for warmer winters at the onset of the PB.

The YD stadial is known from pollen records of southern Alaska, but rarely found in northern Alaska (Mann et al., 2002; Kokorowski et al., 2008). In our pollen record of the Barrow site, the YD is not well pronounced. This includes pollen spectra dated to between 12.4 and $11.5 \mathrm{kyr}$ cal BP both from ice wedges and the sedimentary sequence. Consequently, we postulate for northern Alaska that the YD cold phase is more pronounced in winter than in summer. This underlines the potential of combining of paleoecological (summer) proxies such as pollen with ice-wedge stable isotope (winter) records, which might be helpful to indicate the paleo-seasonality of climate processes. Such a continuous stable-isotope sequence from ice wedges reflecting winter temperature trends during LateglacialHolocene transition at a relatively high (likely centennial) resolution was recovered for the first time. The Barrow ice wedge $\delta^{18} \mathrm{O}$ record shows a prominent decrease and subsequent increase bracketing the YD cold stadial, which is strikingly similar to the $\delta^{18} \mathrm{O}$ record of the North GRIP ice core in Greenland (Steffensen et al., 2008). This finding highlights the potential of permafrost, especially ice wedges as winter paleoclimate archives, which may expand the spatially-restricted glacier ice records to larger continental areas of the Northern Hemisphere. A more detailed discussion of this subject has been recently published by Meyer et al. (2010).

The upper contact of the ice wedge to the sediment(Fig. 3) displays a perfect linear relationship in the co-isotope diagram, This clearly demonstrates two-component mixing of texture ice and ice wedge ice, influencing at least $7 \mathrm{~cm}$ (by extrapolation likely about $15 \mathrm{~cm}$ ) beneath the contact sediment - top of ice wedge, (Fig. 10). Since we know the PB age of this contact at the burial of the ice wedge system, we roughly estimate the isotopic exchange at the top of the ice wedge to be around $10-15 \mathrm{~cm}$ during $10 \mathrm{kyr}$. Therefore, samples taken from the top of ice wedges or from the bottom of the sediment column above ice wedges must be interpreted with caution for paleoclimatic purposes. The lateral influence between ice wedge and sediment has been demonstrated before (Meyer et al., 2002a). In the Barrow permafrost tunnel, the first two or three ice wedge samples adjacent to the lateral contacts $\left(\mathrm{A}, \mathrm{E}, \mathrm{C}^{\prime}\right)$ show a heavier isotopic composition than other samples of stable isotope cluster 1 (Fig. 9). This is likely related also to exchange processes between ice wedge and sediment and, thus, not climate-relevant. Michel (1990) found that wedge ice may bear little relationship to that of the surrounding sediment due to the different geneses of wedge ice and texture ice. Isotopic and also ionic exchange is presumably driven by moisture migration of bound water (Meyer et al., 2002a), which tends to compensate potential differences either in ion concentration or temperature (Yershov, 1998). Therefore, these samples were discarded from paleoclimatic interpretation and the first accepted sample was at $30 \mathrm{~cm}$ distance 
from the lateral contacts. This influence is higher than that at the vertical contact, because the contact with unit II sediments is olderbetween 21.7 (dated sediment) and $12.4 \mathrm{kyr}$ BP (oldest dated ice wedge sample) - as compared to the unit III sediments overlying the ice wedge system. Thus, we deduce an isotopic exchange rate at the contacts of the buried ice-wedge system of around $15 \mathrm{~cm}$ per $10 \mathrm{kyr}$.

The apparent width of the ice wedges is about $6 \pm 1 \mathrm{~m}$. The radiocarbon dates suggest that the ice-wedge system was presumably formed in about 3000 years. Consequently, a mean horizontal growth rate of about one meter wedge ice in about 500 years is estimated, corresponding to an average annual growth rate of $2 \mathrm{~mm}_{\text {year }}{ }^{-1}$. This is in the same order of magnitude compared to the mean thickness of observed ice veins of about 1-6 mm, which would signify rather frequent frost cracking events and a very active period of ice wedge formation at this location (Black, 1963). The growth rate of samples dated to the YD cold event seem to be larger than for the warmer $\mathrm{PB}$ and $\mathrm{AD}$ suggesting more active frost cracking and/or thicker ice veins during the YD.

Ten samples of organic matter enclosed in the Barrow ice-wedge system were directly dated by means of AMS ${ }^{14} \mathrm{C}$. A similar course of the isotope profiling from the lateral contacts of the ice wedge-sediment inwards (Fig. 9) lets us assume that all three contacts (A, E, C') with the sediment and all minima and maxima reflect the same periods in time. This assumption is confirmed by two ${ }^{14} \mathrm{C}$ ages exactly at the same position of the Barrow ice wedge $\delta^{18} \mathrm{O}$ curve $(10,730 \pm 60$ and $10,740 \pm 60 \mathrm{yr}$ BP with $\delta^{18} \mathrm{O}$ of $-25.8 \%$, as well as $11,310 \pm 45 \mathrm{yr}$ $\mathrm{BP}$ and $11,250 \pm 90 \mathrm{yr} \mathrm{BP}$ with respective $\delta^{18} \mathrm{O}$ of $-23.3 \%$ and $-22.7 \%$ ). Therefore, we conclude first, that the radiocarbon dates of organic matter in the ice-wedge system are valid and second, that the ice wedges grew continuously and regularly with older ages at the edges and younger ages in the middle of the ice wedge. The symmetry of the stable isotope profiles nicely confirms the hypothesis of icewedge growth introduced by Lachenbruch (1962) and Dostovalov and Popov (1966).

\section{Conclusions}

Detailed results of geochronological, sedimentological and palynological studies of the buried ice-wedge system and surrounding sediments reflect different stages of Late Pleistocene and Holocene paleoenvironmental evolution of the Barrow, Alaska, area including the MW and LW, AD, YD and PB. The studied sequence comprises major environmental changes from cold and dry climatic conditions during MW and LW to warmer and wetter conditions in AD and PB.

Geocryological observations and stable isotope records of this buried ice-wedge system enclosed in the sedimentary sequence confirm the intersection of two ice wedges with isotopically different clusters. This ice-wedge system was formed in about 3000 years from the end of the LW to the PB and subsequently buried by sediment, that froze to form a 3-3.5 m thick, ice-rich overburden.

Continuous ice-wedge growth is verified by a radiocarbon-dated stable-water isotope sequence, thus yielding for the first time a continuous Lateglacial-Early Holocene winter climate record at relatively high (about centennial) resolution. Relatively warm winter temperatures are reflected in ice wedges formed during the Bølling-Allerød interstadial (12.4-11.3 kyr BP), but also characterized by low $\mathrm{CH}_{4}$ concentrations in wedge ice. The YD cold event is clearly visible in the Barrow ice-wedge isotope record between 10.7 and $10.2 \mathrm{kyr} \mathrm{BP}$, but only weakly pronounced in the Barrow YD pollen spectra. The YD is characterized by most active frost cracking and by higher $\mathrm{CH}_{4}$ concentrations in wedge ice. This underlines temporal variability of ice-wedge growth, and gives additional insight especially into the seasonality and spatial distribution of YD evidence in East Beringia. We conclude that the YD was especially related to the winter season in northern Alaska. A sharp rise of the winter temperatures is visible in the ice-wedge $\delta^{18} \mathrm{O}$ record at around $9.9 \mathrm{kyr}$ BP at the beginning of the PB. The Barrow ice-wedge isotope variations are similar to those observed in the $\delta^{18} \mathrm{O}$ record of the North GRIP ice core in Greenland, highlighting the potential of ice wedges as permafrost climate archives. Both, at the lateral and vertical contacts between ice-wedge system and enclosing sediments, isotope exchange processes took place (presumably driven by moisture migration of bound water) and altered the original isotope signal of the ice wedge. These samples have been discarded from paleoenvironmental interpretation. Paleoecological, hydrochemical and stable isotope characteristics of highly saline, unfrozen pore waters (brines) under the permafrost tunnel indicate a nonmarine origin of the brine water supposedly from an estuarine environment.

\section{Acknowledgements}

Field logistics was provided by the Barrow Arctic Research Consortium (BASC) in support of the U.S. National Science Foundation Project OPP-0327664, Barrow Permafrost Observatory, University of Alaska, Vladimir E. Romanovsky, Principal Investigator. The site is owned by the Ukpeagvik Iñupiat Corporation (UIC, the Barrow Village Corporation). Bart Ahsogeak, former Director, UIC Real Estate, provided valuable assistance in re-opening the vertical access shaft and the construction and installation of the new insulated portal. UIC Real Estate also provided permits to access and use the privately-owned land. Without the generous and timely support of the UIC and BASC, this project would not have been possible. We also acknowledge the former Naval Arctic Research Laboratory (NARL) for its logistical support of the project in the early 1960s and to the Cold Regions Research and Engineering Laboratory for its sponsorship of the original Frozen Ground Project, including those who assisted in the original excavations and geological investigations. We thank the National Climate Data Center (NCDC) of the National Oceanic and Atmospheric Administration (NOAA) for available climate data for Barrow. The authors thank the laboratory teams of the AWI in Potsdam and Bremerhaven for general assistance during sample preparation and analysis, especially Ute Bastian, Antje Eulenburg, Eileen Nebel and Lutz Schoenicke. We acknowledge critical comments by the following: Wendy Eisner (University of Cincinnati) and Paul V. Sellmann (CRREL). The detailed and constructive comments of two anonymous reviewers and QSR`s editorial team namely Dr. C. Hillaire-Marcel are greatly appreciated.

\section{References}

Ager, T.A., 1982. Vegetational history of western Alaska during the Wisconsin glacial interval and the Holocene. In: Hopkins, D.M., Matthews Jr., J.V., Schweger, C.E., Young, S.B. (Eds.), Paleoecology of Beringia. Academic Press, New York, pp. 75-93.

Alley, R.B., 2000. The Younger Dryas cold interval as viewed from central Greenland. Quaternary Science Reviews 19, 213-226.

Anderson, P.M., 1985. Late Quaternary vegetational change in the Kotzebue Sound area, northwest Alaska. Quaternary Research 24, 307-321.

Anderson, P.M., 1988. Late Quaternary pollen records from the Kobuk and Noatak River drainages, northwestern Alaska. Quaternary Research 29, 263-276.

Anderson, P.M., Reanier, R.E., Brubaker, L.B., 1988. Late Quaternary vegetational history of the Black River region in northeastern Alaska. Canadian Journal of Earth Sciences 25, 84-94.

Anderson, P.M., Brubaker, L.B., 1994. Vegetation history of north-central Alaska: a mapped summary of late-Quaternary pollen data. Quaternary Science Reviews 13, 71-92.

Berglund, B.E., Ralska-Jasiewiczowa, M., 1986. Pollen analysis and pollen diagrams. In: Berglund, B. (Ed.), Handbook of Holocene Palaeoecology and Palaeohydrology. Interscience, New York, pp. 455-484

Black, R.F., 1963. Les coins de glace et le gel permanent dans le Nord de l'Alaska. Annales de Geographie 72 (391), 59-91. in French. 
Black, R.F., 1964. Gubik formation of Quaternary age in northern Alaska. U.S. Geological Survey Professional Paper 302-C, pp. 59-91.

Bradley, R.S., England, J.H., 2008. The younger dryas and the sea of ancient ice. Quaternary Research 70,1-10.

Brewer, M.C., 1958. Some results of geothermal investigations of permafrost in northern Alaska. EOS Transactions AGU 39, 19-26.

Brigham, J.K., 1985. Marine stratigraphy and amino-acid geochronology of the Gubik Formation, western Arctic Coastal Plain, Alaska. U.S. Geological Survey. Open File Report 85-381, pp. 1-218.

Brigham-Grette, J., Hopkins, D., 1995. Emergent marine record and paleoclimate of the last interglaciation along the Northwest Alaskan Coast. Quaternary Research 43, 159-173.

Brown, J., 1963. Ice-wedge chemistry and related frozen ground processes, Barrow, Alaska. Proceedings, Permafrost International Conference (Purdue University), NAS-NRC, Publication 1287, Washington, DC, pp. 94-98.

Brown, J., 1965. Radiocarbon dating, Barrow, Alaska. Arctic 18 (1), 36-47.

Brown, J., 1967. Tundra soils formed over ice wedges, Northern Alaska. Soil Science Society of America Proceedings 31, 686-691.

Brown, J., 1969a. Buried soils associated with permafrost. Symposium on Pedology and Quaternary Research, 115-127.

Brown, J., 1969b. Ionic concentration gradients in permafrost, Barrow, Alaska. U.S. Army Corps of Engineers, Cold Regions Research and Engineering Laboratory (CREEL), Hanover, NH, CRREL Research Report 273, 26 pp.

Brown, J., Sellmann, P.V., 1966. Radiocarbon dating of coastal peat, Barrow, Alaska. Science 153, 299-300.

Brown, J., Everett, K.R., Webber, P.J., Maclean Jr., S.F., Murray, D.E., 1980. The coastal tundra at barrow. In: Brown, J., et al. (Eds.). An Arctic Ecosystem: The Coastal Tundra at Barrow, Alaska. Dowden Hutchinson, and Ross Inc., pp. 1-29. Available from: http://www.mblwhoilibrary.org/databases/brown/index.html.

Brown, J., Jorgenson, M.T., Smith, O.P., Lee, W., 2003. Long-term rates of erosion and carbon input, Elson Lagoon, Barrow, Alaska. In: Phillips, M., Springman, S.M., Arenson, L.U. (Eds.), ICOP 2003 Permafrost: Proceedings of the Eighth International Conference on Permafrost. A.A. Balkema Publishers, Netherlands, pp. 101-106.

Brubaker, L.B., Garfinkel, H.L., Edwards, M.E., 1983. A late-Wisconsin and Holocene vegetation history from the central Brooks Range: implications for Alaskan paleoecology. Quaternary Research 20, 194-214

Bunt, J.S., Rovina, A.D., 1955. Microbiological studies of some subantarctic soils. Journal of Soil Science 6, 119-128.

Craig, H., 1961. Isotopic variations in meteoric waters. Science 133, 1702-1703.

Colinvaux, P.A., 1964. Origin of ice ages. Pollen evidence from Arctic Alaska. Science $145,707-708$.

Dansgaard, W., 1964. Stable isotopes in precipitation. Tellus 16 (4), 436-468.

Dostovalov, B.N., Popov, A.I., 1966. Polygonal systems of ice-wedge and conditions of their permafrost. In: Proceedings, First International Conference on Permafrost, Ottawa, vol. 1287. National Academy Science, National Research Council of Canada Publication, pp. 102-113.

Eisner, W.R., Colinvaux, P.A., 1992. Late Quaternary pollen records from Oil Lake and Feniak Lake, Alaska, USA. Arctic and Alpine Research 24, 56-63.

Eisner, W.R., Bockheim, J.G., Hinkel, K.M., Brown, T.A., Nelson, F.E., Peterson, K.M. Jones, B.M., 2005. Paleoenvironmental analyses of an organic deposit from an erosional landsacape remnant, Arctic Coastal Plain of Alaska. Palaeogeography, Palaeoclimatology, Palaeecology 217, 187-204.

Elias, S.A., Short, S.K., Nelson, C.H., Birks, H.H., 1996. Life and times of the Bering land bridge. Nature 382, 60-63.

Frenzel, P., Viehberg, F.A., 2004. Checklist of Recent und Quaternary ostracods (Crustacea) from freshwater, brackish and marine environments in Mecklenburg-Vorpommern, NE Germany. Revista Española de Micropaleontología 36 (1), 29-55.

Faegri, K., Iversen, J., 1989. In: Faegri, K., Kaland, P.E., Krzyinski, K. (Eds.), Textbook of Pollen Analysis, fourth ed. Wiley, Chichester, 200 pp.

Faas, R.W., 1966. Paleoecology of an arctic estuary. Arctic 19 (4), 343-348.

Fleischer, E., Goldberg, M., Gat, J.R., Magaritz, M., 1977. Isotopic composition of formation waters from deep drillings in southern Israel. Geochim. Cosmochim. Acta 41, 511-525.

Gat, J.R., 1996. Oxygen and hydrogen isotopes in the hydrologic cycle. Annual Review of Earth and Planetary Sciences 24, 225-262.

Grimm, E., 1991. TILIA and TILIAGRAPH. Illinois State Museum, Springfield.

Hinkel, K.M., Eisner, W.R., Bockheim, J.G., Nelson, F.E., Peterson, K.M., Dai, X., 2003. Spatial extent, age, and carbon stocks in drained thaw lake basins on the Barrow Peninsula, Alaska. Arctic, Antarctic and Alpine Research 35, 291-300.

Hinkel, K.M., Frohn, R.C., Nelson, F.E., Eisner, W.R., Beck, R.A., 2005. Morphometric and spatial analysis of thaw lakes and drained thaw lake basins in the Western Arctic coastal plain, Alaska. Permafrost and Periglacial Processes 16, 327-341.

Hoefs, J., 1997. In: Stable Isotope Geochemistry, fourth ed., Springer-Verlag, Berlin, Germany, 201 pp

Hopkins, D.M., 1982. Aspects of the paleogeography of Beringia during the late Pleistocene. In: Hopkins, D.M., Matthews Jr., J.V., Schweger, C.E., Young, S.B (Eds.), Paleoecology of Beringia. Academic Press, New York, pp. 3-28.

Hussey, K.M., Michelson, R.W., 1966. Tundra relief features near Point Barrow, Alaska. Arctic 19, 162-184.

Isotope Hydrology Information System. The ISOHIS Database, 2006. IAEA. Available from: http://www.iaea.org/water

Jorgenson, T., Yoshikawa, K., Kanevskiy, M., Shur, Y., Romanovsky, V., Marchenko, S., Grosse, G., Brown, J., Jones, B., 2008. Permafrost characteristics of Alaska - a new permafrost map of Alaska. In: Kane, D.L., Hinkel, K.M. (Eds.), Ninth International Conference on Permafrost. Institute of Northern Engineering, Proceedings. University of Alaska Fairbanks.

Kaufman, D.S., Manley, W.F., 2004. Pleistocene maximum and Late Wisconsinian glacier extents across Alaska, USA. In: Ehlers, J., Gibbard, P.L. (Eds.), Quaternary Glaciations - Extent and Chronology, Part II. Elsevier, pp. 9-27.

Keigwin, L.D., Donnelly, J.P., Cook, M.S., Driscoll, N.W., Brigham-Grette, J., 2006 Rapid sea-level rise and Holocene climate in the Chukchi Sea. Geology 34 861-864.

Kohfahl, C., Rodríguez, M., Fenk, C., Menz, C., Benavente, J., Hubberten, H., Meyer, H., Paul, L., Knappe, A., López-Geta, J.A., Pekdeger, A., 2008. Characterising flow regime and interrelation between surface-water and ground-water in the Fuente de Piedra salt lake basin by means of stable isotopes, hydrogeochemical and hydraulic data. Journal of Hydrology 351, 170-187.

Kokorowski, H.D., Anderson, P.M., Mock, C.J., Lozhkin, A.V., 2008. A re-evaluation and spatial analysis of evidence for a Younger Dryas climatic reversal in Beringia. Quaternary Science Reviews 27, 1710-1722.

Lachenbruch, A.H., 1962. Mechanics of thermal contraction cracks and ice-wedge polygons in permafrost. Geological Society of America Special Paper 70 69pp.

Mackay, J.R., 1974. Ice wedge cracks, Garry Island. NWT. Canadian Journal of Earth Sciences 11, 1366-1383.

Mackay, J.R., 1983. Oxygen isotopic variation in permafrost, Tuktoyaktuk peninsula area, Northwest Territories. Paper of the Geological Survey Canada 18 (B), 67-74.

Mann, D.H., Peteet, D.M., Reanier, R.E., Kunz, M.L., 2002. Responses of an arctic landscape to Late Glacial and early Holocene climate changes: the importance of moisture. Quaternary Science Reviews 21, 997-1021.

MacDonald, M.G., Beilman, W.D., Kremenetski, V.K., Sheng, Y., Smith, C.L., Velichko, A.A., 2006. Rapid early development of circumarctic peatlands and atmospheric $\mathrm{CH}_{4}$ and $\mathrm{CO}_{2}$ variations. Science 314, 285-288.

Meisch, C., 2000. Freshwater Ostracoda of Western and Central Europe. Spektrum Akademischer Verlag, Heidelberg, Berlin, $522 \mathrm{pp}$.

Meyer, H., Schönicke, L., Wand, U., Hubberten, H.-W., Friedrichsen, H., 2000. Isotope studies of hydrogen and oxygen in ground ice - experiences with the equilibration technique. Isotopes in Environmental and Health Studies 36, 133-149.

Meyer, H., Siegert, C., Dereviagin, A., Hubberten, H.-W., 2002a. Paleoclimatic studies on Bykovsky Peninsula, North Siberia - hydrogen and oxygen isotopes in ground ice. Polarforschung 70, 37-51.

Meyer, H., Dereviagin, A.Y., Siegert, C., Schirrmeister, L., Hubberten, H.-W., 2002b. Paleoclimate reconstruction on Big Lyakhovsky Island, North Siberia hydrogen and oxygen isotopes in ice wedges. Permafrost and Periglacial Processes 13, 91-105.

Meyer, H., Schirrmeister, L., Yoshikawa, K., Opel, T., Wetterich, S., Hubberten, H.-W., Brown, J., 2010. Permafrost evidence for severe winter cooling during the Younger Dryas in northern Alaska. Geophysical Research Letters 37, L03501.

Michel, F.A., 1990. Isotopic composition of ice-wedge ice in northwestern Canada. Proceedings, Fifth Canadian Permafrost Conference, Nordicana 54, 5-9.

Nadeau, M.J., Schleicher, M., Grootes, P.M., Erlenkeuser, H., Gottdang, A., Mous, D.J.W. Sarnthein, J.M., Willkomm, H., 1997. The Leibniz-Labor facility at the ChristianAlbrecht-University, Kiel, Germany. Nuclear Instruments and Methods in Physics Research 123, 22-30.

Nadeau, M.J., Grootes, P.M., Schleicher, M., Hasselberg, P., Rieck, A., Bitterling, M., 1998. Sample throughput and data quality at the Leibniz-Labor AMS facility. Radiocarbon 40, 239-245.

Nelson, F.E., Shiklomanov, N.I., Streletskiy, D.A., Romanovsky, V.E., Yoshikawa, K. Hinkel, K.M., Brown, J., 2008. A permafrost observatory at Barrow, Alaska: longterm observations of active-layer thickness and permafrost temperature. In Kane, D.L., Hinkel, K.M. (Eds.), Ninth International Conference on Permafrost. Institute of Northern Engineering, Proceedings. University of Alaska Fairbanks, pp. 1267-1272.

NOAA (National Oceanic and Atmospheric Administration), 2002. Climatography of the United States No. 81. Monthly Station Normals of Temperature, Precipitation, and Heating and Cooling Degree Days 1971-2000, 50 Alaska. National Climate Data Center. Available from: http://cdo.ncdc.noaa.gov/climatenormals/ clim81/AKnorm.pdf 31.

O’Sullivan, J.B., 1966. Geochemistry of permafrost, Barrow, Alaska. In: Proceedings, International Conference on Permafrost, National Academy of Sciences. National Research Council, Washington, DC, pp. 30-37. Publication 1287.

Reimer, P.J., Baillie, M.G.L., Bard, E., Bayliss, A., Beck, J.W., Bertrand, C.J.H., Blackwell, P.G., Buck, C.E., Burr, G.S., Cutler, K.B., Damon, P.E., Edwards, R.L., Fairbanks, R.G., Friedrich, M., Guilderson, T.P., Hogg, A.G., Hughen, K.A., Kromer, B., McCormac, F.G., Manning, S.W., Ramsey, C.B., Reimer, R.W., Remmele, S., Southon, J.R., Stuiver, M., Talamo, S., Taylor, F.W., van der Plicht, J. Weyhenmeyer, C.E., 2004. IntCal04 terrestrial radiocarbon age calibration, 26-0 ka BP. Radiocarbon 46, 1029-1058.

Sellmann, P.V., Brown, J., 1973. Stratigraphy and diagenesis of perennially frozen sediments in the Barrow, Alaska, region. In: Permafrost: North American Contribution, Second International Conference. National Academy of Sciences, Washington, DC 171-181.

Steffensen, J.P., Andersen, K.K., Bigler, M., Clausen, H.B., Dahl-Jensen, D., Fischer, H., Goto-Azuma, K., Hansson, M., Johnsen, S.J., Jouzel, J., Masson-Delmotte, V., Popp, T., Rasmussen, S.O., Röthlisberger, R., Ruth, U., Stauffer, B., SiggaardAndersen, M.-L., Sveinbjörnsdóttir, A.E., Svensson, A., White, J.W.C., 2008. Highresolution Greenland ice core data show abrupt climate change happens in few years. Science 321, 680-684. 
Vaikmäe, R., 1989. Oxygen isotopes in permafrost and ground ice - a new tool for paleoclimatic investigations. 5th Working Meeting Isotopes in Nature, Proceedings, Leipzig, pp. 543-553.

Van Geel, B., 2001. Non-pollen palynomorphs. In: Smol, J.P., Birks, H.J.B., Last, W.M., Bradley, R.S., Alverson, K. (Eds.), Tracking Environmental Change Using Lake Sediments. Terrestrial, Algal and Silicaceous Indicators, vol. 3. Kluwer, Dordrecht, pp. 99-119.

Vasil'chuk, Y.K., 1992. Oxygen Isotope Composition of Ground Ice - Application to Paleogeocryological Reconstructions, vol. 1. Moscow State University Publishers, Moscow, 420 pp. (in Russian).

Vasil'chuk, Y.K., 2006. Ice wedge: heterocyclicity, heterogeneity, heterochroneity. Moscow, Russia, 404 pp. (in Russian).

Vasil'chuk, Y.K., van der Plicht, J., Jungner, H., Vasil'chuk, A.C., 2000. AMS-dating of Late Pleistocene and Holocene syngenetic ice wedges. Nuclear Instruments and
Methods in Physics Research Section B: Beam Interactions with Materials and Atoms 172, 637-641.

Wagner, D., Gattinger, A., Embacher, A., Pfeiffer, E.-M., Schloter, M., Lipski, A., 2007. Methanogenic activity and biomass in Holocene permafrost deposits of the Lena Delta, Siberian Arctic and its implication for the global methane budget. Global Change Biology 13, 1089-1099.

Yershov, E.D., 1998. General Geocryology. Studies in Polar Research. Cambridge University Press, Cambridge, UK, 580 pp.

Yin, Y., Geiger, W., Martens, K., 1999. Effects of genotype and environment on phenotypic variability in Limnocythere inopinata (Crustacea, Ostracoda). Hydrobiologia 400, 85-114.

Yoshikawa, K., Romanovsky, V., Duxbury, N., Brown, J., Tsapin, A., 2004. The use of geophysical methods to discriminate between brine layers and freshwater taliks in permafrost regions. Journal of Glaciology and Geocryology 26, 301-309. 